Portland State University

PDXScholar

1975

\title{
A preliminary evaluation of the Independent Living Subsidy Program in the Model Cities area
}

\author{
W. Patrick Frawley \\ Portland State University \\ Mary Goodwin Gossart \\ Portland State University
}

Follow this and additional works at: https://pdxscholar.library.pdx.edu/open_access_etds

Part of the Child Psychology Commons, Social Welfare Commons, and the Social Work Commons Let us know how access to this document benefits you.

\section{Recommended Citation}

Frawley, W. Patrick and Gossart, Mary Goodwin, "A preliminary evaluation of the Independent Living Subsidy Program in the Model Cities area" (1975). Dissertations and Theses. Paper 1764.

https://doi.org/10.15760/etd.1763

This Thesis is brought to you for free and open access. It has been accepted for inclusion in Dissertations and Theses by an authorized administrator of PDXScholar. Please contact us if we can make this document more accessible: pdxscholar@pdx.edu. 
A PRWIIMINARY BVALUATION OF THE

INDEPENDENT IIVING SUBSIDY PROGRAM

IN THE MODEL CITIES ARAA

by

W. PATRICK FRAWLEY

MARY GOODWIN GOSSART

A report submitted in partial fulfillment of the requirements for the degree of

MASTER OF SOCIAL WORK

Portlend State Univeraity

School of Social Work 1975

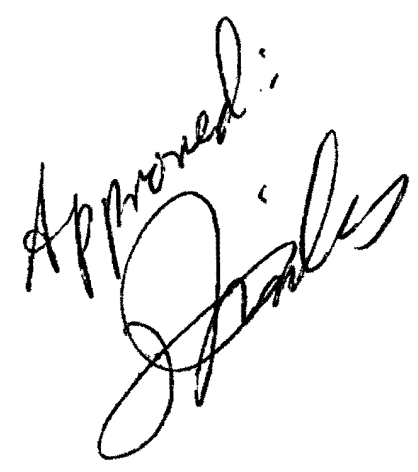




\section{TABLE OF CONTENTS}

\section{PAGE}

\section{CHAPTER}

I INTRODUCTION....................... I

II REVIEW OF IITERATURE................. 8

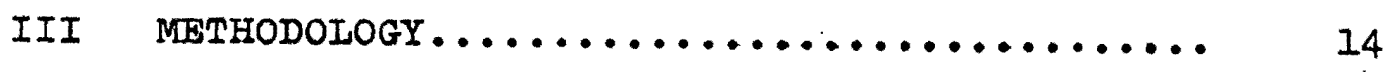

IV ANALYSIS OF DATA................... 22

v RECOMMENDATIONS AND CONCLUSIONS.......... 34

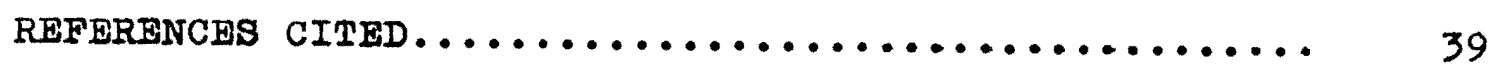

APPENDIX A................................ 40

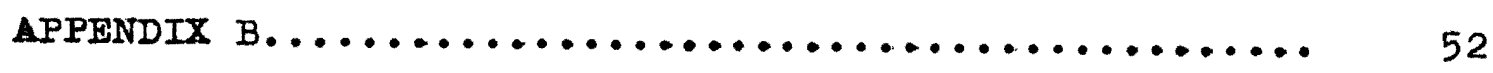




\section{CHAPTER I}

\section{INTRODUCTION}

This is a descriptive and analytical study of the twelve adolescents who have participated in the Independent Iiving Subsidy Program (IISP) in the Model Cities area of Portland. It is an assessment of the program's impact on the adolescents in working toward the goals of independence and self-sufficiency.

The concept of a program which would subsidize out-ofhome care for certain adolescents in living facilities of their own, with a measure of independence, was conceived by a caseworker at the Children's Services Division (CSD) and an administrator of a children's residential care facility. In his work with young people the caseworker encountered frustration in dealing with a segment of the youngsters who came to the agency's attention. "These kids were those who, for any number of reasons, were being kicked around. Some had been bounced from one substitute care program to another. Some had no parents, no family. Some were ending up on the streete, living from hand to mouth. But all were still the responsibility of the state because they were under age." (Oxegonien, Aug. 4, 1974) No existing program seemed to meet the needs of these youngsters. Substitute care programs such as foster care, group home care, residential or institutionel 
care had either been tried or were not appropriate. No one was able to take responsibility for these youngsters and see that their needs would be met. At the same time they were too young to take full responsibility for themselves.

The IISP was passed into law during the 1973 Oregon State Iegislature as House Bill 2499. The law allowed "independent resident facilities" to be established for certain minors. It also authorized the payment of grants to these minors for rent, food, clothing, and incidental expenses. CSD was to establish program policies and administer the program. The Legislature authorized $\$ 50,000$ to implement the program in two areas of the state. Eugene and the Model Cities area of Portland were chosen, and each received $\$ 25,000$ to establish an Independent Iiving Subsidy Program. The program became operational in February, 1974 and each area can support approximately ten participants. The program was established for minors who were at least sixteen years of age, and in need of out-of-home care. To be eligible, they need to have already been placed without success in two or more foster homes, group homes, youth care centers or institutions. The participants of the Model Cities IISP, the program which is the subject of this study and evaluation, averaged five different placements prior to their admission into the IISP. The program was designed for young people whose social background is so disruptive that they cannot be expected to adjust to a family setting. The IISP offers a living arrangement other than a family or 
institutional setting. The minor is given the opportunity to live with a degree of independence while pursuing his education, vocational training, or career. The ILSP offers the adolescent a vehicle whereby he can progress from a degree of financial and advisory dependence on the state to a position of independence and self-sufficiency.

The goal of the IISP is the development of the adolescent's capacity for assuming the adult responsibilities of caring for oneself, being self-sufficient, as well as being self-aupporting. The practice of allowing the adolescent some independence and responsibility while in the program is new and innovative. No other models of such a program could be found.

The amount of responsibility the adolescents in the program may assume varies with their capacities. Some may need more assistance in assuming responsibilities for such things as money management, or proper care of their residence, or even themselves. There may be temporary "fallures" in meeting responsibilities, such as not paying a bill on time. However, the youngster still takes responsibility for this, and in this example he may be required to rebudget and perhaps do without some luxury item in order to meet the bill. He is allowed and encouraged to learn from his "failures". As he grows in responsibility, he takes on further responsibilities.

In our atudy of the Model Cities IISP we felt it was important to have an understanding of the backgrounds of the 
adolescents prior to entry into the program. As we wanted to look at changes in the adolescent after being in the program, we needed to know where he stood upon entering the program. No measurement had been taken prior to entry which would enable us to establish a baseline for comparison. Yet just to begin to draw up a measure we needed some sense of where they stood upon entering the program in regard to the variables we intended to measure them against. Did they enter at a high level of functioning in the areas of education, employment, money management, responsibility and selfconfidence? Or were they what could be termed a "high risk" population, functioning at a much lower level? A review of admission data on the youngsters gave us some sense of the kinds of youngsters the program was serving.

Previously we stated the population averaged five placements prior to their admission into the program. (See Table 1, column. 3, Appendix B for the number of substitute care placements of each participant). With so many moves could we expect such a youngster to be up to grade level in school? Should we expect such a youngster to have a high level of self-confidence, which normally develops from a sense of being valued and loved? The family backgrounds indicated a pattern of large families, with many siblings. The predominant marital pettern for the parents was separation or divorce, sometimes with a remarriage. Many of the participants were wards of the court. There were complaints of neglect and, in some cases, of incorrigibility. Background 
data on income was not gathered. However, given the geographical area of Model Cities, one can essume the youngsters to be from low income families.

Such background data gave us a general sense of a baseline for the variables we were going to measure. We were dealing with a "high risk" population and might expect a higher than average failure rate. We were also dealing with a population that was not middle class and did not possess a high level of social and work skills. For such a population tasks such as being on time for work were reported as a newly acquired skill. Achievement of such tasks would represent movement from the baseline of previous functioning. The variables we set out to measure were the areas where the program is attempting to bring about positive change in the participants. These nine objectives are: additional school credits, additional vocational skills, money earned, amount contributed to support, living within budget, cooperation with worker, relating to others, selfconfidence, and responsibility. These axe the areas around which we developed our measure. We wanted to determine where the participants stood in these areas after being in the program.

The administration of the IISP is carried out by a permanent review committee. The committee is composed of the district director for Model Cities CSD, Lewis Winchester; a member of the supervisory staff, June Robertson; a project consultant, Bruce Titus; the out-of-home placement liason 
worker, Larry Fleming; and one other "at-large" member designated by the district director. The committee determines who shall be admitted to and terminated from the program. They also periodically review (every three to four months) the progress of participants. Application for admission to the program is made on behalf of the adolescent by his caseworker. The worker submits written material consisting of a profile summary, personality sssessment, a statement of how the program would benefit the youth, a tentative budget, and his statement of willingness to assume the necessary responsibilities. Caseworkers whose youngaters are admitted to the program are required to take on additional responsibilities of supervision of the youngster. Applicants and their workers are then interviewed by the review committee, who vote to determine whether or not the applicant should be admitted.

Once accepted into the program the adolescent and his worker must appear periodically before the committee for a review of the youngster's progress in the program. At this time movement toward the program's objective of selfsufficiency is discussed, as well as any other areas where progreas or problems may have been experienced.

Another requirement for those newly admitted members of the IISP is that the youngater and his worker must produce a written agreement; this is called the contract. This document details specific goals and objectives which both parties agree to, and spells out the responsibilities of each 
person in reaching them. The contract is to be reviewed monthly to assess the adolescent's progress toward selfsufficiency. If necessary it can be modified or changed. A sample contract is enclosed in Appendix B.

Monthly grant payments for rent and utilities, food, clothing, transportation, school expenses and other incidental expenses are made directly to the adolescent. The participants also receive medical coverage. Monthly budgets are usually made by the adolescent, often with the assistance of his caseworker. The adolescent is given a degree of responsibility for managing his money. The monthly allotment each youngster receives varies with his income from employment or other sources, i.e., parents, educational grants, etc. The maximum grant payment allowed is $\$ 350$ per month. The structure of the IISP is such that grant payments are made to the participants so that they may be established in "independent living facilities". Such an arrangement allows the youngster an exercise in responsibility, teaches him to live independently, to manage money, and to handle the routine business of meeting personal needs. Concurrently, the youngster is required to be engaged in full time activity. geared toward the goal of self-sufficiency. He may be engaged in school, employment, or vocational training activities on a full time basis, or a combination of two or more of these on a part time basis. 


\section{CHAPTER II}

\section{REVIEW OF LITERATURE}

Our review of the literature for the task of evaluating this program covered four related areas. First, we began to familiarize ourselves with some of the litexature on evaluative research in generel. To assist us in the development of our measurement, a questionnaire, we turned to the Iiterature on means of measurement. Third, an overview of the broad area of adolescence was undertaken to assist us with the task of gearing our measure to the adolescent population we were studying. Finally, to put this program in the broader perspective of the system of child welfare services, some exploration of the child welfare system in Oregon was made.

The literature we examined on evaluative research was all relatively current. The material indicated the field and practice of evaluating social welfare programs is more recently being recognized in importance. Many funding sources are now beginning to require that an evaluation component be included in new programs submitted to them. Public and private agencies are now more than ever being held accountable to the public taxpayer for demonstrating the return that is gotten for his dollar.

$$
\text { Weiss (1972) discusses the value of evaluations in }
$$


providing information about programs on which important decisions can be based. Evaluations can answer questions for the policy makers, program directors, and the practitioners. Policy makers are supplied with information from evaluations to make decisions about the continuation, expansion, or cutback of programs or services. Program directors can utilize the information to improve the procedures of their program. Practitioners can look to evaluation results with an eye to changing their activities or techniques to maximize fevorable outcomes.

Evaluations of program outcomes provide policy makers with some basis for their decisions, but as Weiss points out, other factors may come into play. The public's receptivity or community's acceptance of a program must be weighed. The reaction of those participating in a program is another factor to be considered. The other alternatives for the group receiving service come into play. If there are few other altematives, or if the other alternatives prove poor, a program with a small outcome may be the best alternative. Cost is often a critical factor in determining the future of a program. Outcome must often be looked at and compared with the price one has to pay for such results. The nature and purpose of evaluation, according to Weiss, becomes clear. It addresses itself to the question, "How well is the program meeting the purposes for which it was established?" It measures the extent to which these goals are achieved in order to make decisions about a program 
and its improvement. The first step in evaluation is then to define and state the goals of a program in such a way that they can be measured. What is a particular program trying to achieve? In Weiss' experience this is not an easy question to get a consensus on. Another question Weiss posed and which we found ourselves addressing was who is to make the measurement as to the extent the goals have been achieved. The possibilities are program participants or clients, staff, or an outsider, such as an impartial rater, or some measures suggest using relatives of clients.

Some of the problems of our developing a research design for evaluating a social welfare program are discussed by Weiss et al (1972). There is difficulty in getting a "baseline measure" or a picture of where the client is before entering a program or receiving a service. Beginning our evaluation while the program was in progress did not allow for the establishment of a baseline with which to compare the state of affairs after time in the program. Control groups, a.similar group not involved in the program, are also difficult for the evaluator to set up to utilize as a basis for comparison with program participants. To address the problem of how we were to measure the effects of this program we searched the Iiterature for a model. A review of the Abstracts of Disertations and Theses and the NASW Abstracts for Social Work yielded no study of a similar program and no measurement which we could use as a model. Realizing we would have to develop our own measurement 
in the form of a questionnaire we turned to the literature on measurement for some ideas on how best to proceed. Bonjean (1967) was useful in giving us an idea of the different measures developed and where to find them.

Shaw (1967) provided us with two questionnaires which had been developed and utilized to measure self-confidence, which was one of the variables we wanted to measure. From the two questionnaires, comprised of between forty and fifty questions each, we saw the scope of measurement one variable could entail. We chose those questions we thought to be the beet indicators of self-confidence for our population.

Maizel (1971) was useful in our development of questions eround employment for the adolescents in our study. He had developed and utilized a questionnaire for adolescents, exploring such aspects of their employment as learning new. skills on the job, and their relations with people at work. Reviewing this questionnaire enabled us to look at some different aspects of employment, and to decide which aspects we wished to focus on for our study.

We found the works of Gold (1969) and Zachry (1940) relevant to our exploration of the adolescent's relationships with others. These works explored the social woxld of the teensgex. They discussed the people in the adolescent's world - the parents, other adults such as teachers, employers and relatives, and the crucially important peer group. With a clearer picture of the teenager's social world we were able to design our questionnaire to measure his/her level of 
functioning in the area of relating to others.

Our last area of exploration in the literature was brief but important in addreseing some crucial issues found in such a program as the IISP. One issue which this study does not address is the need in the community for such a program. If a community doesn't have a population which needs such a program, the question of whether or not the program "works" becomes secondary.

The Iiterature on child welfare needs in Oregon sheds some light on the question of the need for such a program. Greenleighs (1968) looked at the problem of out-of-home care for children in Oregon, and found it to be "one of the primary problems in Oregon." He states, "Oregon has been in a state of crisis with respect to its public out-of-home care programs for children for a number of years," and, "every year an increased number of children need out-of-home care." He mentions the adolescent as posing greater difficulty than others in finding out-of-home care. Such data indicate the need for out-of-home care programs and a lack of such programs for adolescents.

A conference in Portland on "Purchase of Child Care Services" (1972) reported on "Care and Services for Children Outside Their own Homes." They prioritized the problems of out-of-home care. Third on a list of eleven was the gaps which existed in service programs to meet the needs of certain children. They proposed an assessment of Bervice needs and plans to meet the needs not met by existing service programs. 
The IISP program was designed to serve the adolescent who would not be appropriate for existing out-of-home care programs. The population of the program would not be in need of reaidential treatment, group home care, foster care, or institutionalization. They were in need of out-of-home care, but no existing program was appropriate. They fell between the cracks created by the gaps in programs. The IISP is a program meeting a need not met by any of these other programs. 


\section{CHAPTER III}

\section{METHODOLOGY}

The process of evaluating this social welfare program began as all program evaluations must, with an exploration of what the program was trying to do (its objectives), and the methods (the hows) it was employing. To accomplish auch a task it was necessary for us, as "out-of-house" evaluators, to talk with administrators, practitioners, and program participants. Meetings were held with varioue members of the review committee, which served as administrative staff.

We first met with the program's monitor, a member of the eupervisory staff who performs a majority of administrative functions, and at the same time we made contact with the program's consultant, who also serves as a caseworker for two of the program's participants. Much of our understanding of the program's objectives and methods came from these two people. To assure that our evaluation had further administrative support and sanction we met with the director of the Model Cities CSD, who is also a committee member. To further understand how the program operated we were invited to attend a meeting of the review committee. Here we were given the opportunity to meet the remaining members of the committee, some of the program participants and their caseworkers. At this meeting we were able to observe how a 
participant's review proceeds, as well as the committee's procedure for admitting an applicant.

Once we gained an understanding of the objectives and methods of the program, our next task was to decide the focus of our evaluation. The program staff left this decision fairly open. The IISP required an evaluation component but no outcome study was included or built into the program. No money or staff were provided for the task of evaluation. There was interest and concern on the part of staff that funding for the program be maintained or even expanded. Clients were coming in requesting this service of the agency. There was desire on the part of administrators to demonotrate to the legislature and public the effectiveness of the program. Practitioners were interested in evaluation geared toward enhancing any positive impact on the client, by improving the methods of the program's operation.

We considered doing a cost analysis by comparing the total cost in money, time, personnel of this program with other out-of-home care programs wuch as foster care, group home care, and institutional care. We considered some sort of community impact atudy. A case history or "systems" approach to evaluation was also discussed. We settled on an evaluation design which would attempt to measure the extent to which the program was meeting its objectives of positive change in its participanta. We felt a cost analysis is limited unless one can first determine what one gets for his money. The program seemed too young and amall scale to 
attempt a community impact study.

We realized the difficulties we would encounter in using a quasi-experimental design to measure change. One problem related to control for other variables other than the program, which might bring about change. A participant might become more self-confident after being in the program, but could we conclude this was primarily due to the program and not some other factor? A control group i.e., a group similar in all respects except one, not receiving this service, would solve this problem. As is the case with many sociel welfare programs, such a group was not established or available. Our other problem was the difficulty in establishing a baseline. In the areas in which we wanted to measure change, we did not know (in the sense of an established measurement) where the participants stood prior to entry into the program. As an example, if we didn't know a youngster's level of responsibility when he entered the program, how could we determine if, as a result of the program, he was more responsible?

Our review of the Iiterature yielded no evidence that a similar program had been implemented elsewhere; therefore there wes no existing measure which we could employ to evaluate the program. We considered gathering our data from the case records of the participants. Although background data was available, written data about the youngsters while in the program was insufficient. We needed to develop a measure we could apply to the participants, which would indicate where 
they stood in meeting the program's objectives. These were spelled out on the review committee's evaluation sheets for each youngster. They list these items: "additional school credits, additional vocational skills, amount earned, amount contributed to support, lives within budget, cooperation with worker, relates to others, self-confidence, is responsible." A questionnaire was settled on as the means of measure. We felt this would yield more consistent data than interviews. Measures for each of these variables were spelled out in operational, observable and behavioral terms. We decided to ask participants to rate themselves, and also to have their caseworkers rate them.

In our questionnaire we sought identifying information (age, sex, race, and time in program), thinking we might compare the results with these variables. For example, did females rate higher than males in a particular area, or did those in the program longer rate higher in an area than new members? The variable of additional school credits was measured by questions in quantitative and qualitative terms in a section entitled "Educational Information." (See Appendix B for a copy of the actual questionnaire.) Two aspects of the variable of additional vocational skills were measured. In the education section, information was sought regarding those vocational. skills learned in an education progrem. In the "Employment" section, we sought information regarding vocational skills learned while on the job. To measure the amount earned we asked questions about participants' employ- 
ment. As we wanted to obtain information on attitudes toward these activities of work and school, as well as factual data, question were asked about the value placed on these activities.

The variables of amount contributed to support and Iives within budget were measured by twelve questions around money management. Six questions were posed on the subject of the contracts made between the youths and their caseworkers in the section "You and Your Worker." These contracts spell out more specifically and personally the objectives for each youth. For this reason we sought data which would indicate satisfaction with these objectives and the degree to which they were being met. In this section six questions were also posed to measure the variable of cooperation with worker. Questions were of both a quantitative and qualitative nature, The reader may again refer to the questionnaire.

To measure self-confidence seven statements were developed as indicators of this variable. The participants were asked to respond to statements on a five-point scale, ranging from "true for me all or most of the time" to "rarely or almost never true for me ". The statements were arranged and instructions given to the respondent that he think in terms of the truth of each statement for him now as compared with a year ago. The time lapse of a year was chosen because it was a round figure which would approximate when the respondent entered the IISP. We wanted to determine whether 
the participants (and their workers) saw any change in their attitudes about themselves in the course of a year (or their approximate time in the program). Together, the seven indicators would serve as an overall measure of the level of self-confidence in the participants, as rated by the youths themselves, and by their workers.

Eight measures were developed to rate the youths on the program's objective of improved relationships with others. Both groups of respondents were asked to indicate any improvement in the adolescent's relationships with peers, various family members, and other adults in the youth's life. The last of the nine variables, responsibility, was measured by twelve indicators. They covered three general. areas of responsibility: in handling money, meeting responsibilities to others, and being responsible in meeting personal needs.

The majority of questions or statements allowed the respondent to select his responses from a five-point scale. Two similar scales were utilized. One scale used responses ranging from "strongly agree" to "strongly disagree," and the other scale had responses ranging from "true for me all or most of the time" to "rerely or almost never true for me". In nine questions a four-point scale was used, with responses ranging from "always" to "never". For one statement a threepoint scale was utilized, but we later felt these were not a.s useful or precise as a five-point scale might have been. Initially we had thought in terms of developing 
two questionnaires - one for the youths and another for their caseworkers. We wanted to apply the same measure, but have two raters. So rather than simply reword the measure from the first to the third person (that of the caseworker), we administered the same measure with additional instructions to the caseworkers. (See Appendix B, the cover letter for the questionnaire). The decision to have two raters for this evaluation would offer certain advantages. We would have two judgements on where the client stood in relation to the program's objectives - his own and his worker's. The two judgements might agree and substantiate each other, or they might vastly disagree. Either way, they would give a more accurate picture of the reality of the situation. The two judgements would serve as a check on responses which might otherwise be considered highly subjective.

Once our measure was developed we were anxious to run a pretest, which would serve to indicate any weak areas. The difficulty was in finding a pretest respondent. The measure was applicable only to clients or workers with clients in the ILSP. With such a small population (twelve) to draw from, we did not want to lose any of them by having them take a pretest. We decided on presenting it to two members of the administrative staff for review and critique, and as a result only minor admendments were made.

A time was arranged when we could meet with the participants and their workers to administer the questionnaire. The two groups of respondents met in different rooms, each 
with an evaluator present to answer any questions. Those not in attendance were later provided with questionnaires to be returned to $\mathrm{CSD}$. Of the twenty-four questionnaires distributed, twelve to the participants and twelve to their workers, twenty-one or $87 \frac{1}{2} \%$ were returned. The worker return was $100 \%$, while nine of the twelve youngsters, or $75 \%$, returned their questionnaires. 
CHAPTER IV

ANAIYSIS OF DATA

\section{IDENTIFYING INFORMATION}

We are describing a total population of twelve young men and women. These youngsters range in age from sixteen years to twenty-one years old. Their mean age is eighteen. (See Chart 1, Appendix A). Fight members of the population (two females, six males) axe Black; three other members of the population (two females, one male) are White: and one other member of the population is a Native American girl. There are a total of seven males and five females. (See Chart 2, Appendix A). Time spent in the program (see Chart 3, Appendix A) ranges from one month to one year. The average time of participation is 7.5 months.

\section{EDUCATIONAI INFORMATION}

In terms of school grades completed, the IISP members range from the eighth to the twelfth grade; the mean last grade completed is just short of the eleventh grade. During 1974 eleven IISP members had been involved in various educational programs: five were working to pass their General Educational Development tests, four attended high school, one worked in the Youth Manpower Program, and one girl took 
training in a program at Mt. Hood Community College. (See Chart 4, Appendix A). Five of these people have indicated full-time involvement, five others indicate part-time involvement; one other person did not respond.

Bven though these youngsters have been an average of 7.5 months in the IISP, three of them report having completed their education programs. One young man has graduated from high school, another received his GED certificate, and a third member completed a training program at Mt. Hood Community College. Two of these people have already gone ahead and enrolled in aditional classes. With regard to the question of evaluating their own performance in the various education programs, the response was "average"; in fact, scores for the responses from workers and youngsters were identical $(N=11 ; M=2.88)$.

\section{EMPLOYMENT}

Of the twelve members in the IISP, ten either have been or are currently employed. (Bee Chart 5, Appendix A). The other two reported that they were involved in full-time educational programs. The youngsters who were employed indicate that they have been working in a variety of jobs: two have worked as nurses' aides, others have been employed as food service workers, i.e., busboys, waitresses, and dishwashers. Pay for these jobs has ranged from $\$ 1.90$ per hour to about $\$ 3.00$ per hour; the average pay was about $\$ 2.25$ per hour. Of the ten who were employed, six reported going on for 
second jobs; four of these say that they improved their positions either in terms of money earned or now skills acquired. As an example, one young woman reported that she quit her $\$ 2.00$ per hour job as a waitress in a cafe, and is now working for $\$ 3.00$ per hour as a secretery a Navy recruiting office. The youngsters say that they have landed these jobs mostly through their own initiative. Our analysis of the data shows no significant difference between these responses and those of the workers.

In terms of being significant to our purposes as evaluators, we felt that the final two questions in the Employment section were of great importance. First, the youngsters were asked what they wanted to be doing after having completed the ILSP. Then they were asked if they agreed that their current efforts in work and/or school were helping them to reach these goals. Just as the members differ in personality so do their goals. One girl wants to become an airline stewardess. Another wants to become a counselor or social worker. Some of the members want to work and continue in school, while others want to own their own businesses. But with the second question there was complete agreement. Both workers and youngsters agreed (scores for the responses were identicel) that work and school were going to help them get what they wanted for themselves.

MONEY MANAGEMENT

This section received a very poor response. The 
workers did not respond to seven percent of the questions; the youngsters did not respond to about seventeen percent of the questions. We had arranged the questions around the areas of income, budgeting and money management. Five youngsters reported that their monthly income had changed while in the IISP, but a majority of the youngsters (seven) reported reasonably stable levels of employment earnings. Table $I$, Appendix B indicates specific amounts of employment earnings which the young people have contributed to their own support.

Responses to budgeting questions were arranged and coded on a four-point scale (always, sometimes, rarely, never). The young people were asked if they planned some sort of budget each month. The mean response was 2.75 . When asked if they received any assistance in making out budgets, the mean response was 2.56 , again falling in the range of rarely to sometimes. Three of the nine youngaters who responded to these questions reported that they never received assibtance from anyone. One girl reported getting help from her family, and the remaining five members said they received help from their caseworkers.

Next they were asked to produce a sample monthly budget, by listing amounts spent on the following seven items: rent and utilities, food, school expenses, transportation, clothing, entertainment, and other miscellaneous items. Perhaps since budget making is not a frequent practice among all the IISP members, this part of the questionnaire must have presented 
some problems; the youngsters left blank fully one-third of the sample budget items. With regard to the items which were Iisted, another one-third of the responses disagreed by at leavt $\$ 15.00$ per item each month. This may be of no particular significance in terms of such things as clothing or entertainment, but we thought it a poor reflection that there were such great degrees of disagreement over such basic items as food and rent and utilities. As an example, one youngster said he budgeted $\$ 60.00$ for rent and utilities, and $\$ 20.00$ for food; his worker listed $\$ 110.00$ for rent and utilities, and $\$ 50.00$ for food.

It is interesting to note that in spite of the apparent confusion over how much is spent on various budget items, both clients and workers agree that the youngsters do a good job of responsible money management. Seven of the program members have opened checking and/or savings accounts. Again, the responses for this section were arranged and coded on a four-point scale. We asked if the youngster felt he/she was able to budget and regularly meet bills and expenses. Member responses scored a mean of 3.5 ; worker responses scored a mean of 3.58 . So there seems to be a strong feeling that the youngsters are doing a good job of money management.

\section{YOU AND YOUR WORKER}

For the purpose of comparison in the remaining sections, those worker responses have been eliminated for which we had no corresponding participant response (due to non-return of 
three questionnaires). Data around the area of the contract revealed that eight of the nine responding participents had made a contract with their workers. The "no" response was from a participant in his first month in the program. Therefore the responses for the remaining five questions dealing with the contract have an $\mathrm{N}=8$ for both the participants and workers.

The second question, dealing with satisfaction with the content of the contract, yielded the greatest difference between the clients' and workers' responses. The mean response for the adolescents was 4.25 , and the workers reported a full point lower, 3.25. While the clients report they "agree" (4.0) that "there was nothing in it (the contract) I wanted to change," the workers indicated they were "undecided" (3.0) about this. For a comparison of the mean responses of participants and workers about the contract see Chart 6 , Appendix A. Revision of the contract more to the satisfaction of the workers might be indicated. Or, perhaps the workers' clarification with the client that he (the client) is truly satisfied (as the results indicate) will increase his own Batiafaction with the contract.

Workers and clients responded in a similar manner to the third question about mutually intending to follow through with the conditions of the contract. They both "agree" they intended to follow through, with a mean for this question of 4.12 for both groups of respondents.

The fourth question inquired if there were conditions 
of the contract unfulfilled. The mean response for both groups was not too different; the client mean response being 3.12 and the worker mean 3.37 . The workers did tend more than the clients toward "agree" than "undecided" about this. This points out an awareness on the part of both groups that there may be items in the contract that have not been followed through on. Our next question asked if it was important that these things haven't been done. Our thought was that contracts may need to be changed and modified as circumstances and priorities change. Both groups disagreed that it wasn't important. The question remains if conditions of the contract were important, why then were they not followed through. Revision of the contract after a stated period of time might offer an explanation, and provide both the worker and client with a more workable agreement.

There seems to be a feeling on the part of workers that although they tended to be "undecided" about their satisfaction with the original contract, they felt it important to follow through with it once it was agreed upon. A revision of the original contract might also provide them with a more satisfactory agreement to follow through with, rather than feeling compelled to follow through with an agreement they're not satisfied with.

The final question on the contract asked if the contract was relevant to what clients wanted out of the program. Both groups "agreed" it was, with the youngaters averaging a stronger agreement than the caseworkers. This confirms the 
general trend of workers to be less satisfied with the contract.

Six questions were posed to measure the variable of relationship with the caseworkex. The first three inquired about the quality of the relationship, whereas the last three were more quantitative in nature. The general trend was for participants to rate the worker higher than the worker rated himself. The qualitative traits of "helpful", "available" and "trust" were oredited to the workers by the adolescents. Trust received the highest rating (a mean of 4.9 ), indicating they "strongly agree" that they trust their workers. Availability was rated by the adolescents next highest with a mean of 4.66 , and helpful received a mean response of 4.2

The workers rated themselves consistently lower than the clients did. They rated themselves highest on the trait of available (a mean of 4.1 ), although this was still lower than the client rating. Trust received the next highest rating (a mean of 4.0 ), and helpful received a mean response of 3.9. For a comparison of participant and client means on relationship see Chart 7, Appendix A. The mean of the worker self ratings on the three traits were very similar $(4.1,4.0$ and 3.9), and the differences were insignificant. There was a more significant difference in the clients' rating of the workers on the three traits.

The frequency of contact was reported by, both groups to be on the average a little more than once a week. Both groups agree the contacts are "sometimes" initiated by the 
client and find the number of contacts to be adequate.

\section{ABOUT YOU}

Seven indicators of the variable of self-confidence were administered. Together these seven indicators give us a picture of the level of functioning in the area of selfconfidence from two perspectives - client and worker. A comparison of the mean responses of the two groups is illustrated in Chart 8, Appendix A. On observation the workers' ratings of the clients seem lower. When applying a statistical test for significance, the Mann Whitney $U, p<.001$, we find the workers rated self-confidence on the seven measures significantly lowex than the youngsters. One can speculate why. We might interpret this as the optimism of youth. People may have a tendency to rate themselves higher than others and to think of themselves more positively than others would. The caseworkers might be applying a different and somewhat higher standard.

Both groups do rate the adolescents at an average-toabove-average level of functioning in the area of improved self-confidence. We attempted to make some comparisons of self-confidence ratings based on such variables as sex and time in the IISP program. We wondered whether there would be any significant differences in the ratings. For example, if there was a higher level of self-confidence in those who had been in the program for a longer period of time as compared with those in the program for only a short time, the 
positive change could be attributed to participation in the program.

The difficulty in our making such comparisons was that with such a small sample it wouldn't be possible to base any conclusions on the findings, and the differences would have to be very large to be significant. A look at the profile of the youths and their time in the program (see Chart 3 , Appendix A) shows only three youngsters in the program for a period of less than six months; and this is too small a sample to base any comparison on. We attempted a comparison of male and female self-confidence ratings; but we realized that the sample was too small, and our analysis yielded no significant differences.

Eight indicators of the variable relations with others were developed. The last one received a poor response, most likely due to its placement apart from the others on the following page. For this reason analysis of the response for this last indicator was not possible with such a small number of responses. Therefore seven, rather than eight indicators, will be analyzed. The reader is referred to Chart 9, Appendix A for a graphic illustration of the mean responses for both raters. A higher mean response by the youtho was found for each indicator. This follows the same pattern found in the self-confidence ratings, with the youths rating themelves higher than the workers rated them. The difference would appear to be significant, ranging from a difference of .62 to 1.1 between the two ratera. The grand 
mean of the seven indicators for the participants averaged 4.07 , and 3.2 for the caseworkers. The youths rated the measure of improved relations with others "very often true for me" whereas the workers indicated the measures were more apt to be "occasionally true" for the youths.

The two groups did agree on the indicators which showed most improvement. The indicators of relationships with parents, siblings, other relatives and co-workers $(\# 4,5,6,7$ on Chart 9, Appendix A) were rated higher by both groups than the indicators of relationship with peers $(\# 1,2,3)$. Both the respondents agreed the most improvement was in the youths' improved relationshipe with those other than his peers.

\section{MORE ABOUT YOU}

Twelve measures of responsibility were applied to the areas of money management, responsibility to others, and responsibility to self. Under responsible money management three indicators were developed. The measure of overdram bank accounts yielded a mean response of 2.7 for the youngaters and 1.57 for the workers. The two raters agreed that "sometimes but infrequently" they run up a lot of bills, and "very often" they pay their bills on time.

Four indicators of responsibility with regerd to others were developed. A mean response of 3.44 by the youngsters and 3.82 by the workers was given for the indicator of "regular contact with my familyn. The responses to the other three indicators of responsibility to others are illustrated 
in Chart 10, Appendix A, in addition to the five indicators of responsibility to oneself. For these eight indicators the mean response of the two groups were similar. The grand mean for the youths averaged 3.9 and 3.68 for the workers. Interestingly the same measure, that of "eating things that are good for me," received the lowest rating by both groups. Whereas the youths rated "doing what I say I'II do" highest, their workers rated them highest on "usually being clean and well-groomed."

A comparison of the grand means of the four variables relationship with worker, self-confidence, relations with others, and responsibility - is illustrated in Chart 11, Appendix A. Both groups gave the highest rating to "relationship with worker." Self-confidence received the next highest rating by the youths, and reaponsibility by the workers. Responsibility was given the lowest rating by the youtha, whereas relations with others received the workers' lowest rating. The trend was for the youngsters to rate themselves higher than the caseworkers rated them on each of the four variables. 


\section{CHAPTER V}

\section{RECOMMENDATIONS AND CONCLUSIONS}

A significant part of our data analysis has been descriptive. This is due in part to the nature of ome of the data i.e., types of employment and types of education programs: Another factor is the small population which was available to study. This small sample made it unfeasible to compare such factors as sex, or time in program. Not only does the program have a small population, but it is also relatively new (one year old at the time of study).

The focus of our evaluation was not what the program costs, but what legislators and taxpayers can expect to get for whatevex money they spend. However cost must enter into the picture of any program evaluation. Cost analysis shows that this program has an appealing advantage over many other programs - it is far less expensive. Table 1, Appendix B indicates the "altermate plan and cost per month" for each of the IISP members. The only out-of-home care which is less expensive than the IISP is foster care. So if money is the only criterion, then the choice is clear - go with foster care.

Here is where the budgeters need to turn to the researchers to ask what does each program give us for our money. We have indicated what one can expect from this pro- 
gram. An axticle by Hunter (1964) outlines a 1963 followup of 95 families in Oregon who had taken foster teenagers two years previously; and only 35 still had the teenagers or were even available to take one. Foster care not only doesn't appear successful for teenagers, but also implies the hidden cost of finding homes, trying to work out problems with the family and child so he may remain in the home, and, if he leaves, additional time spent in finding another placement. The same administrative costs are not involved in the IISP. Some attempt was made to design our measure on the basis of comparing levels of present functioning vo. Ievels of functioning at the time of entry into the program. However, what we were able to measure was primarily theix functioning at the time of our study; and this was in the area of the program's objectives, the nine indicators of successful program participation. In retrospect, we did not obtain a firm measure of their functioning in these areas prior to entry into the IISP. What we were able to obtain and analyze was how well and to what degree the youngsters were functioning and meeting the program's objectives. Despite the Iimitations of the study, the data we analyzed allow us to make conclusions in this area. Measurement of functioning by the two groups - workers and participants - yielded more velidity to our conclusions than responses from a single group.

There was general agreement between both groups in the areas of additional school credits, vocational skills, and 
money earned. The fact that $91 \%$ of the participants were earning school credits by participation in education programs, and that $27 \%$ of these youths had completed education programs indicates the program's success in this area. The percent completing education programs appears even more successful in light of the fact that the average amount of time in the ILSP was only 7.5 months.

The data shows a favorable level of achievement for the indicator of employment. $83 \%$ of the youngaters were employed at some time while in the program, and $60 \%$ of them obtained a second job. These figures indicate success in this area more significantly when one considers the current high rate of unemployment, especially for Black teenagers. Two-thirds of our population fall into this category. In evaluating or planning for similar programs, one might expect less success in this area until the employment picture changes.

Table 1, Appendix B, which was developed by CSD staff, shows the "total child's cost to budget", the amount of money he has contributed to his support while in the program. Most participants have contributed a small percentage of the total cost. Two of the youngsters have, in a period of less than a year, become virtually self-supporting; one is employed in the armed forces, and the other as a full-time secretary. The data showe that program members are contributing to their support and moving toward, the objective of becoming selfsupporting. 
The program's objective of Iiving within the budget received a rating indicating some success in this area. The response to the statement "I am able to budget and regularly meet my bills and expenses" rated a mean of 3.5 on a fourpoint scale.

The remeining objectives (good relationships with the worker, improved relations with others, and higher levels of self-confidence and responsibility) all received a rating indicating a high level of achievement. Although the caseworkers rated achievement of these objectives at a lower level, both groups indicate that there is achievement by the participants in these areas.

Our findings indicate that levels of achievement are sufficiently high to conclude that the program's objectives are being met. Such findings would indicate a recommendation to continue the IISP. The period of one year is really too short a time to test the success of a program. This is especially. true when we consider that this program was designed to achieve its goal of self-aufficiency by participants within a two year time frame. For this reason we also recommend a follow-up study at the end of the second year. If money and staff are not budgeted for this purpose by the state, we suggest that other students from the Portland State University School of Sociel Work might be interested in such a study. Modifications of our messure would enable it to be utilized as a pretest. It could be administered to youths as they enter the IISP; and again as a post-test after they 
are out of the program. If no follow-up study is undertaken, then we would recommend that the program utilize some improved method of data keeping, to determine the degree to which the program is successfully meeting its objectives.

While this study is by no means definitive, the satisfactions and positive thrust, with no negatives elicited over more than sixty dimensions, indicate that serious attention should be paid to this type of alternative to traditional program, to say nothing of the alternatives of leaving these young people to their own unsupervised entry into adulthood. 
Bonjean, Charles et al. Sociological Measurement: An "Inventory" of Scales and Indices. (San Francisco, 1967), p. 169-179; 318-325.

Conference on Purchase of Child Care and Services, Proceedinge. (Portland, May, 1972), p. 34-37.

Gold, Martin and Elizabeth Douvan. Adolescent Development, Readings in Research and Theory. (Boston, 1969), p. 259278; 346-375.

Greenleigh Associates, Inc. Child Welfare Needs \& Services In Oregon. (New York, 1968), p. 94-105.

Hunter, I.W. "Foster Homes for Teenagers in Oregon," Children, XI, (November, 1964), p. 234.

Maizels, Joan. Adolescent Needs and the Transition from School to Work. (Iondon, 1971), Appendix.

Olmos, Robert. "State tries giving teen foster children their freedom," The Oregonian, August 4, 1974.

Shaw, Marvin E. and Jack Wright. Scales for Measurement of Attitudes. (New York, 1967), p. 243-264.

Weiss, Carol et al. Evaluating Action Proprams: Readings in Social Action and Education. (Boston, 1972), p. 89-95; 243-249.

Weise, Carol. Evaluation Research. (New Jersey, 1972), p. 3-153.

Zachry, Caroline, Emotion and Conduct in Adolescence. (New York, 1940), p. 263-394. 
APPENDIX A 
Chart 1: Population Profile by Age

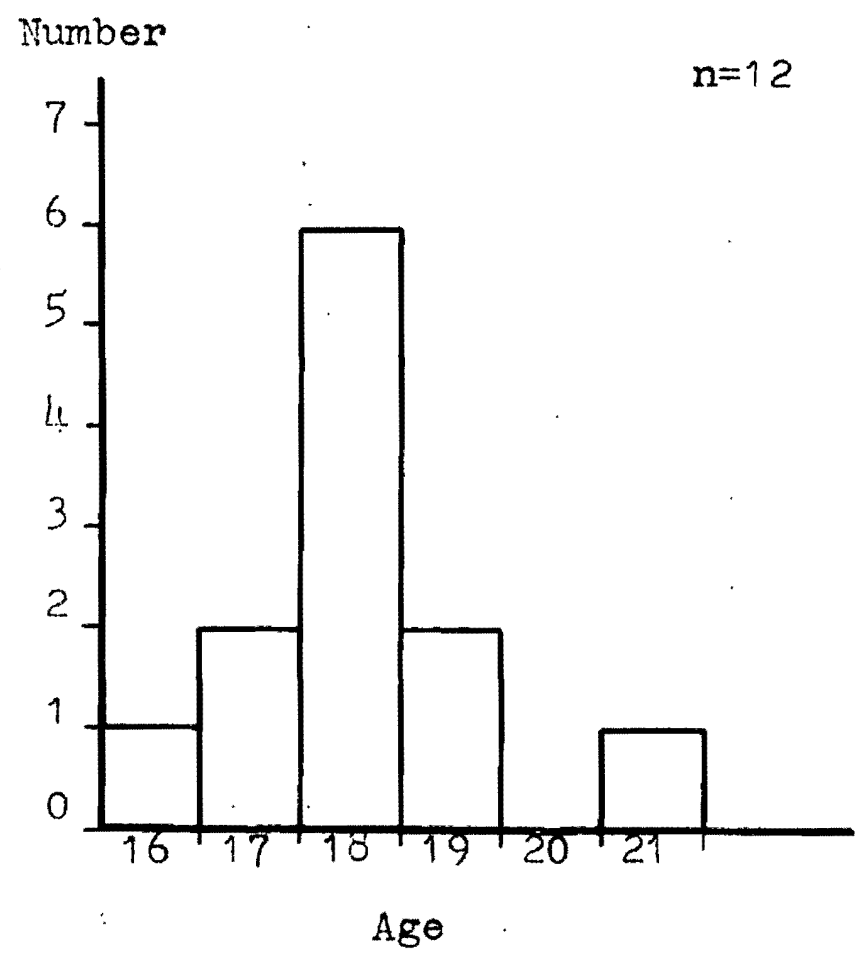


Chart 2: Population Profile by Race

$n=12$

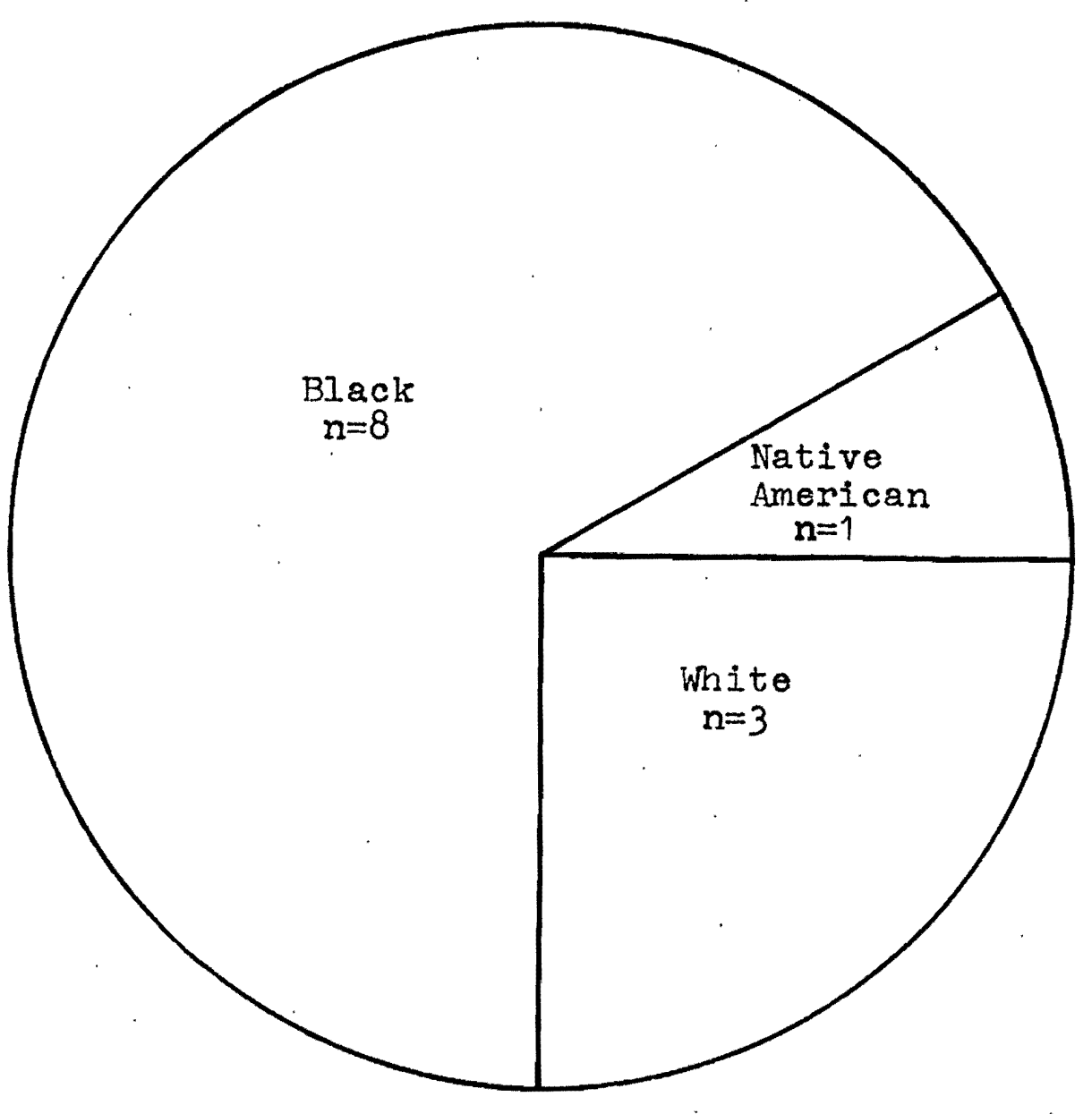


Thart 3: Time in Program

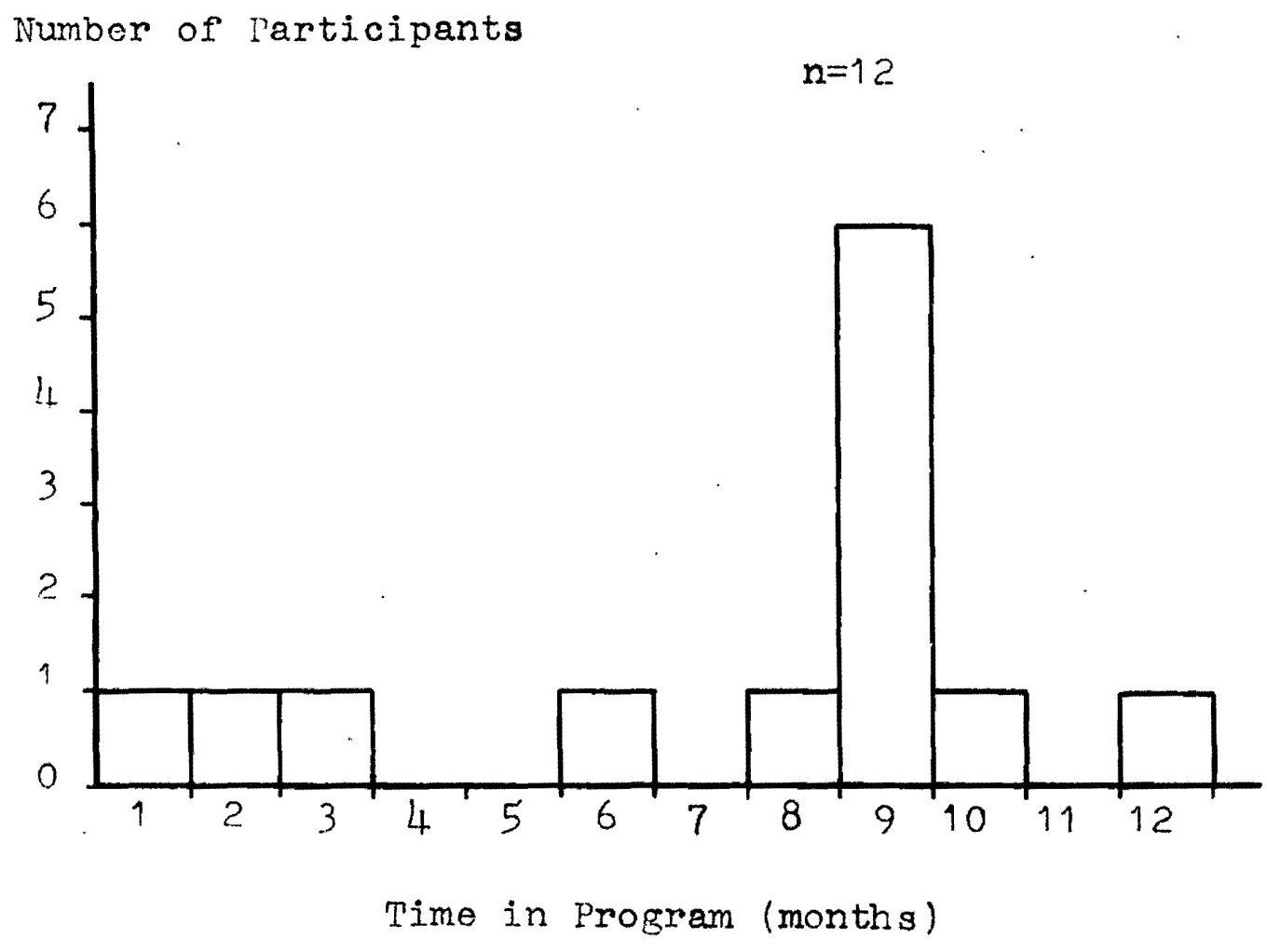

Average Time in Program - 7.5 months 
Chart 4: Tynes of Educational Involvement by Program Participants wile in the IISP

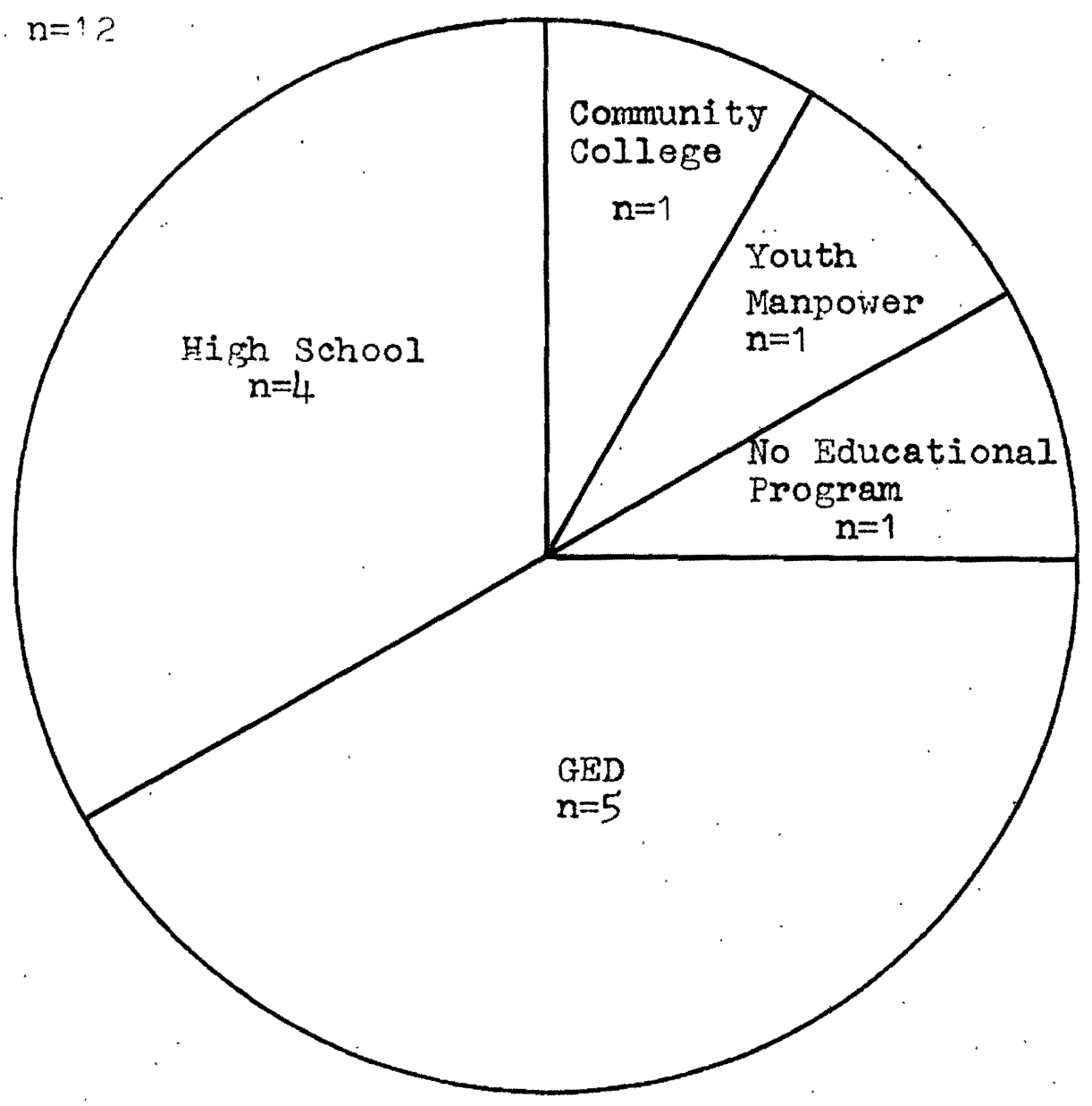


Chart 5: Participants' Employment Picture while in the IISP

Time in Program (months)

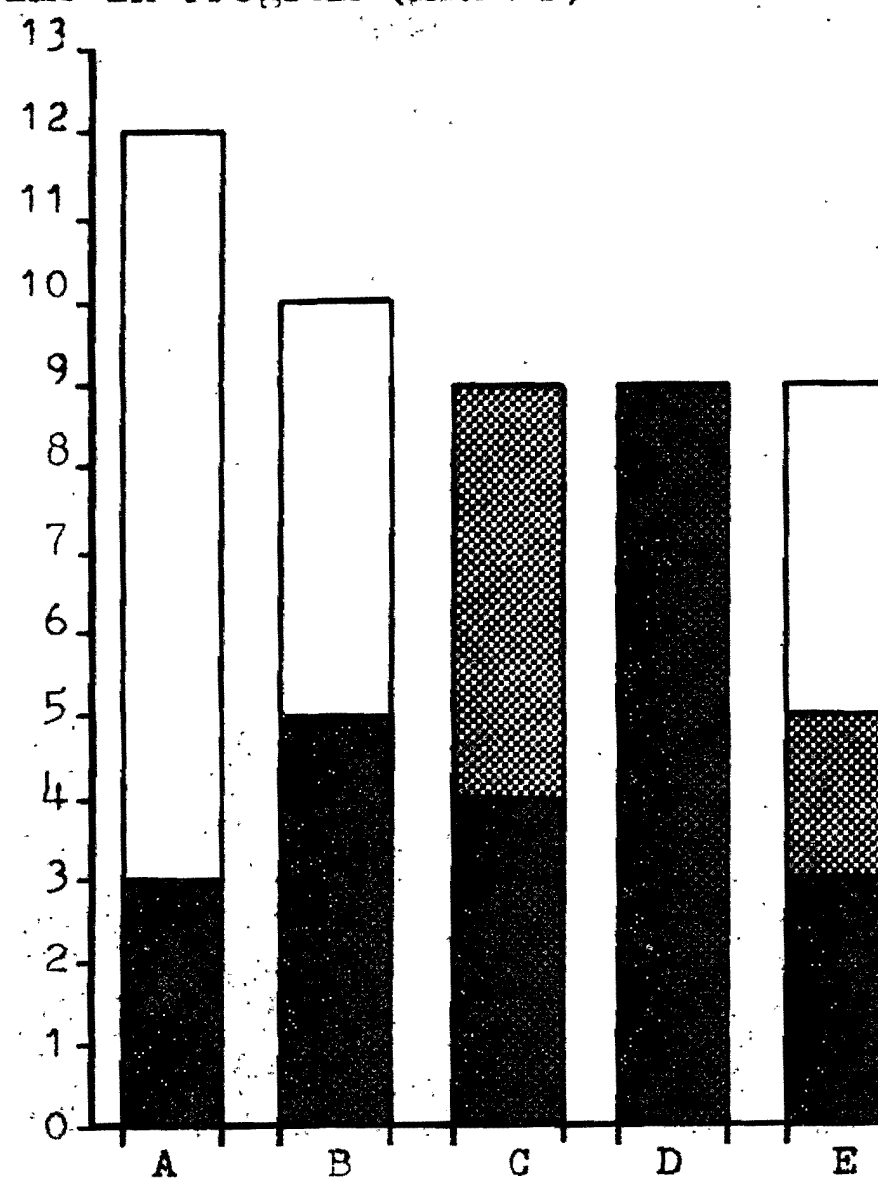

Pime employed at first job rime employed at second job mime employed at third job $\square$ Time not employed

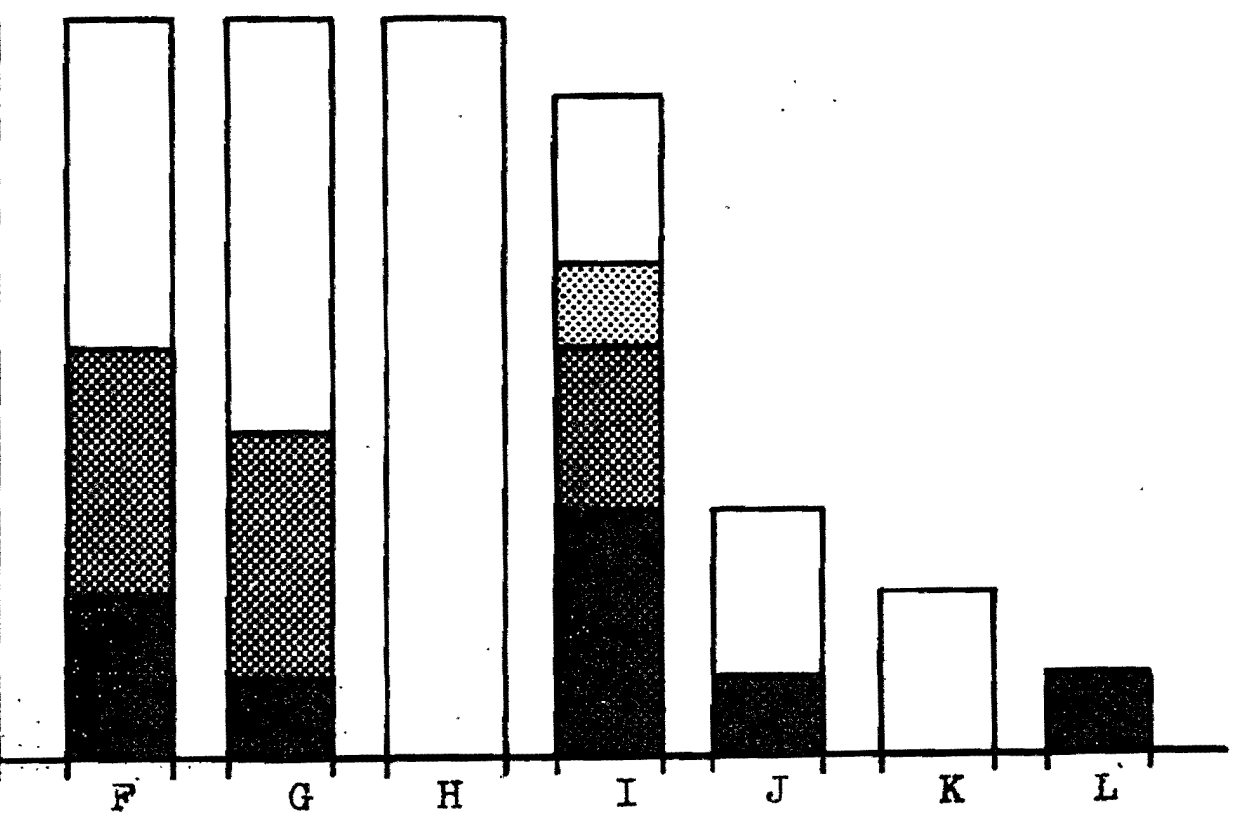
Participant

Average time employed while in the IISP -- 4.16 months 
Mart 6: Participant and Worker Means on the Five Questions Dealing with the Contract (You and Your Worker questions 2 - 6)

Rating

$n=8$

Strongly 5.0 Aspos

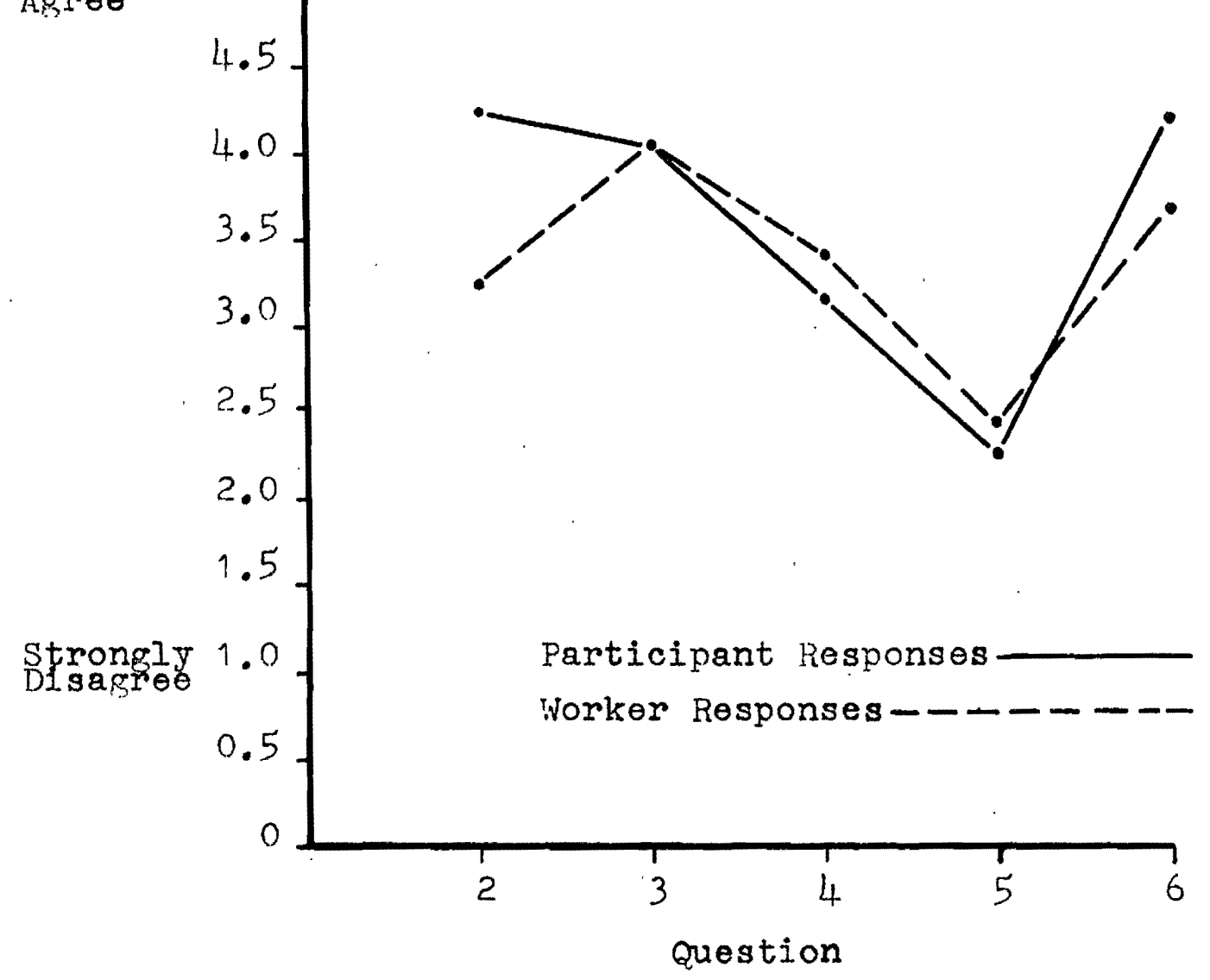


Chart 7: Participant and Norker Means on the Three Questions Regarding the quality of the Relationship with the Caseworker (You and Your Worker questions 7 - 9)

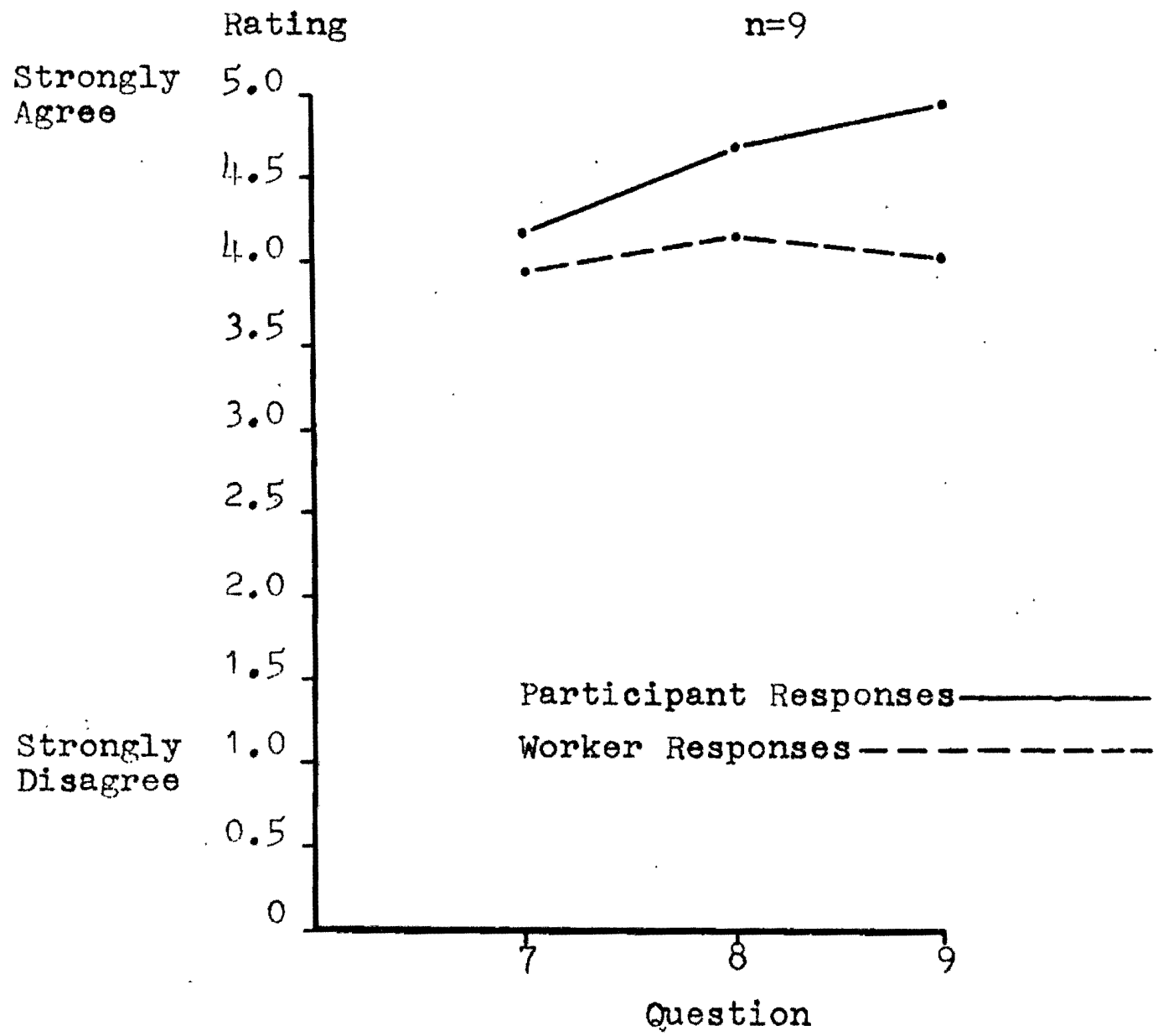


Chant 8: Means of Self-Confidence Ratings by Participants and Workers (About You questions 1 - ?)

A - True for all or most of the time

E -- Rarely or almost never true for me $n=9$

Rating

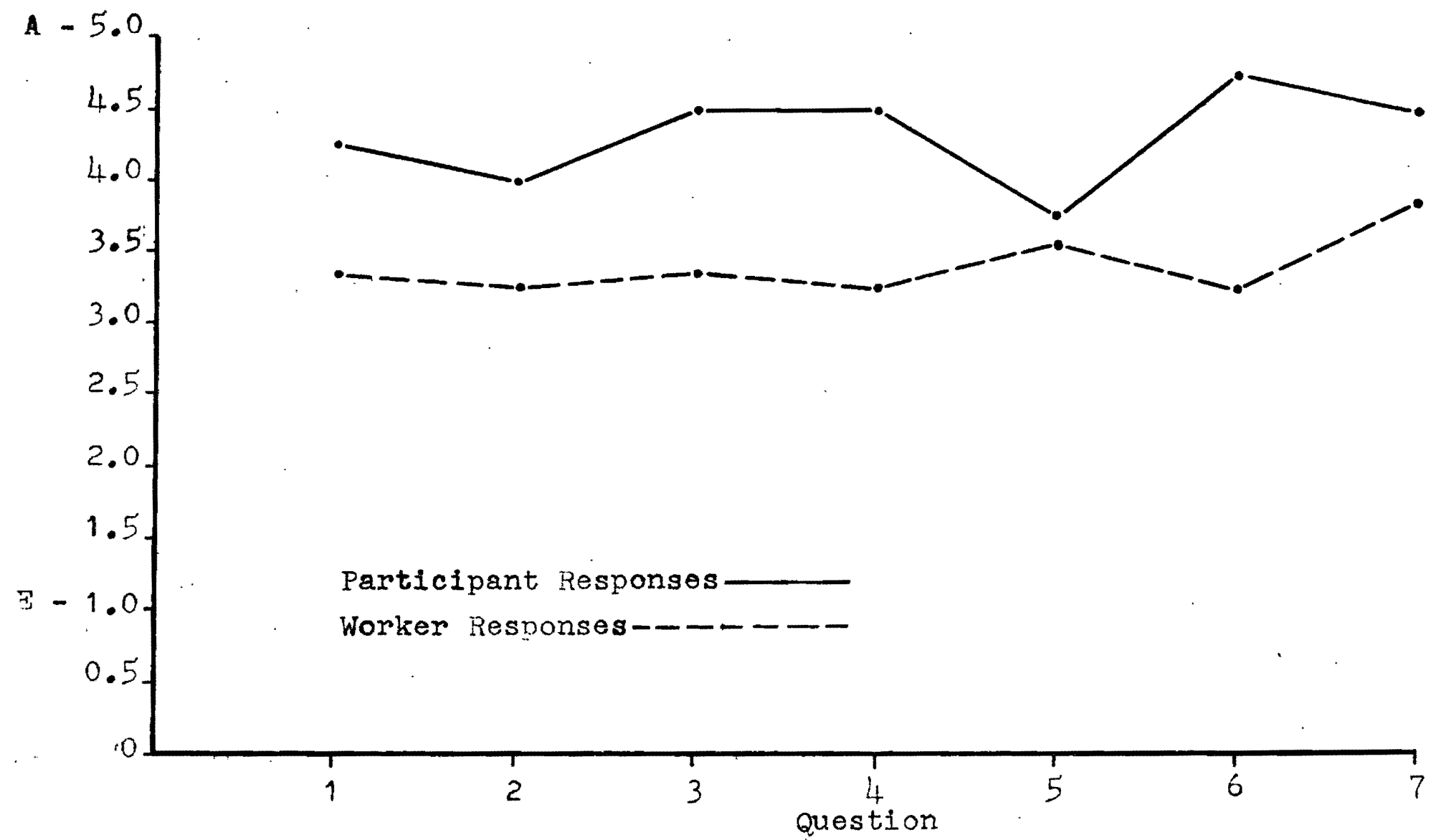


Chart 9: Mean Responses of Participants and Workers on the Seven Meesures of Relationships with Others (About You questions $8-14$ )

Rating

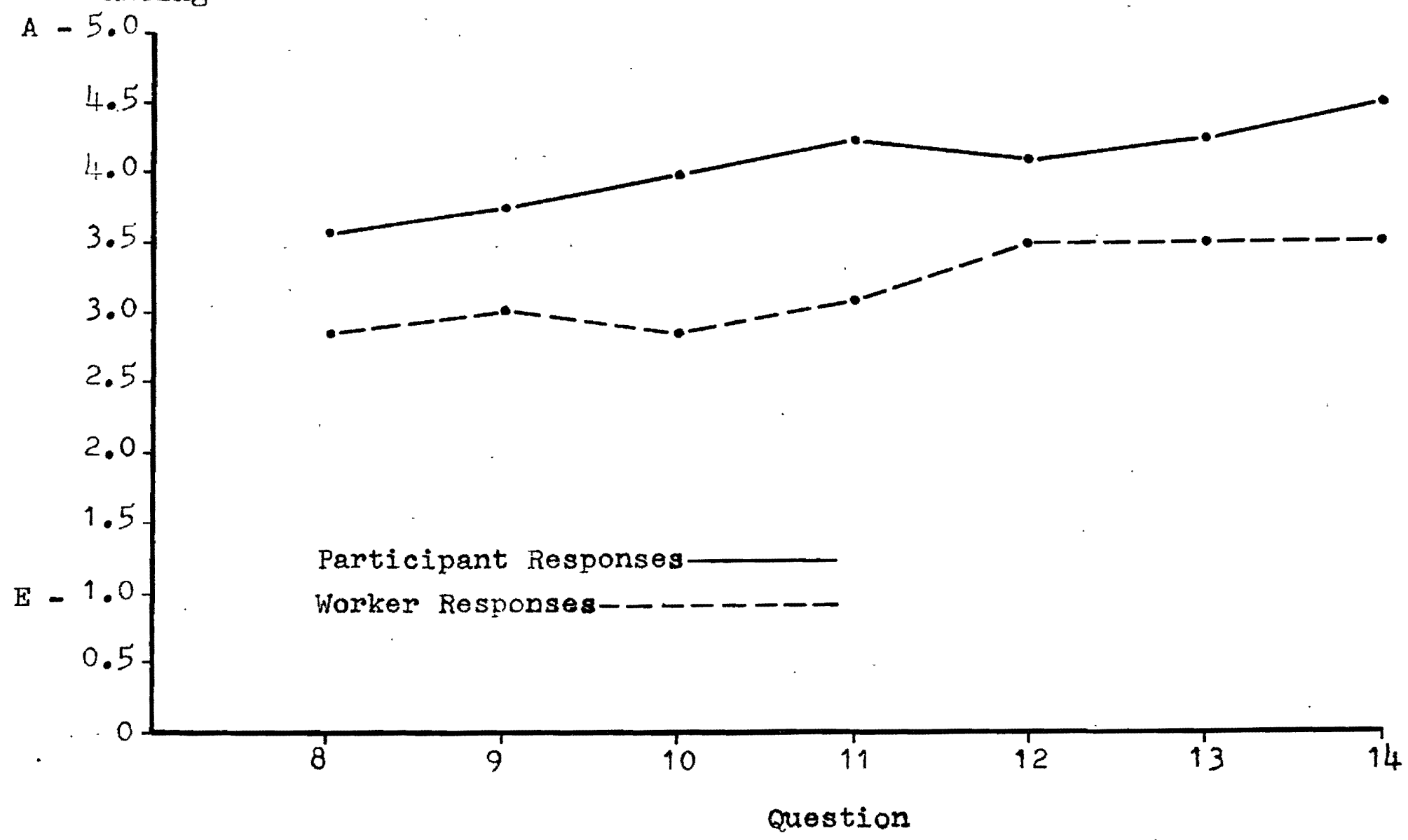


Chart 10: Hean Responses of Participants and Workers on Eight lieasures of Responsibility (More About You questions 5 - 12)

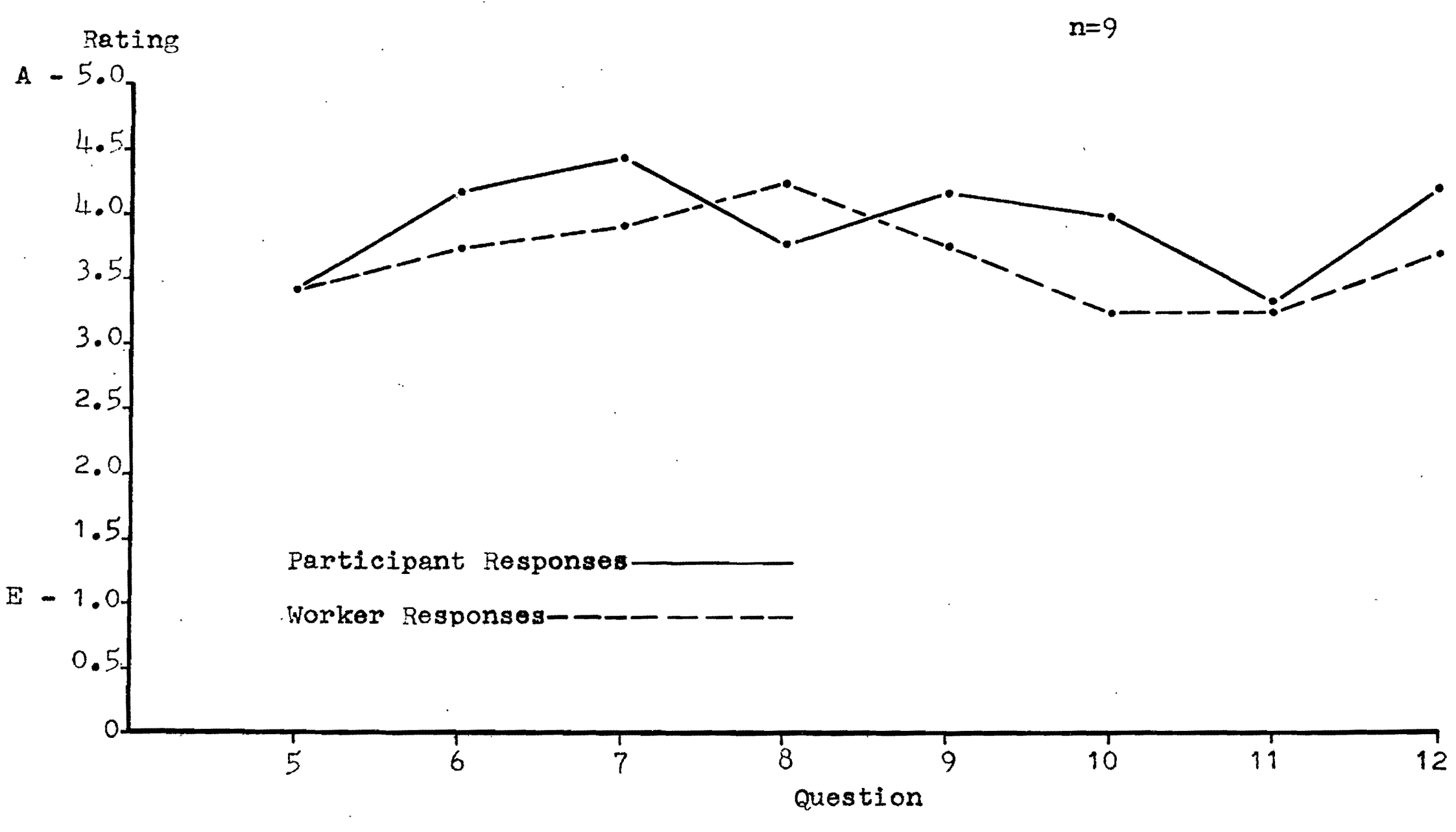




\section{Chart 11: Grand Means of Four Variables}

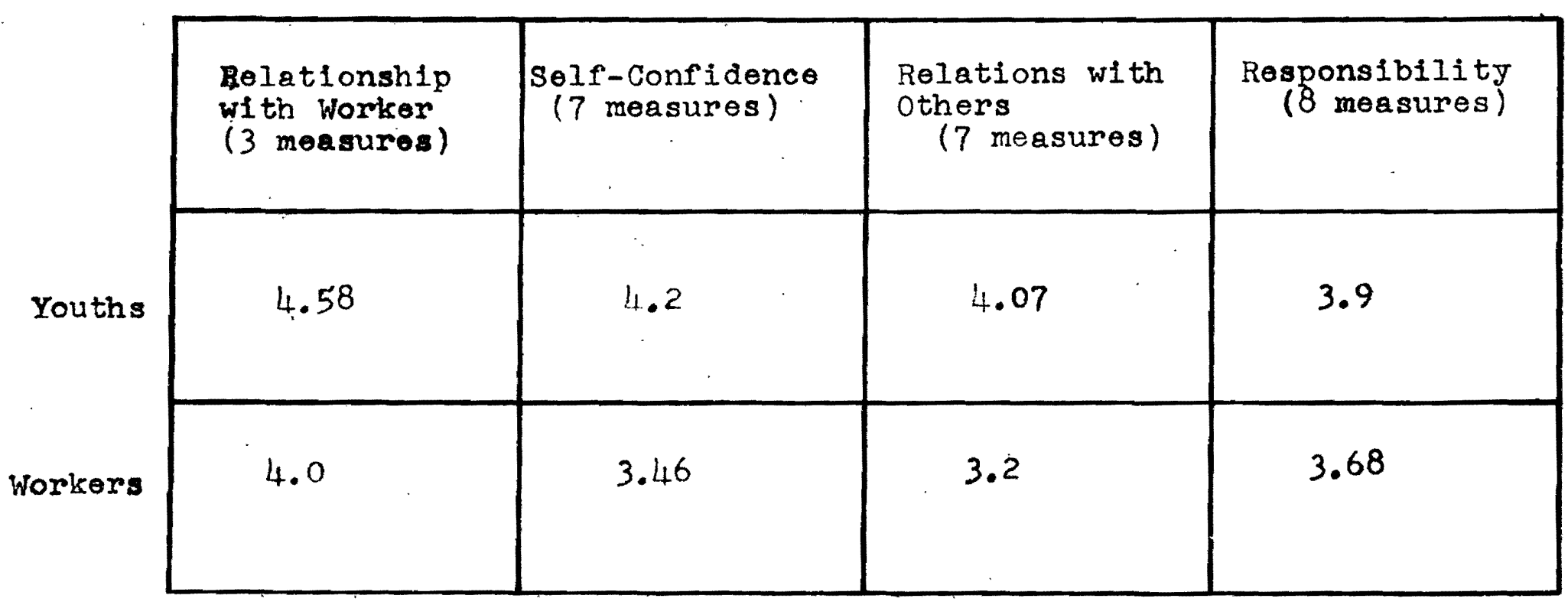




\section{APPENDIX B}




\section{SAMPIE INDEPENDENT LIVING SUBSIDY PROGRAM}

\section{AGREEMENT BETWEEN CLIENT AND WORKER}

\section{GENERAI}

The purpose of this agreement is to define certain obligations. William Jones must abide by them to enter and remain in the Independent Living Subsidy Program. The agreement also defines the obligations Joe Davis has in supporting William in the program. Both William and Joe agree that if both follow through with the terms written below that william will become self-sufficient no later than November I, 1975.

William Jones will contact Joe Davis, either by phone or office visit, at least once per week and will be available to meet with him at least once every two weeks for a three month period. Joe Davis will help William plan the following month's budget by the 15th of each month and will see that the money to subsidize his income is available to him by the first of each month.

\section{EDUCATION}

William Jones will continue to attend Jefferson High School until June, 1974. He will maintain grades high enough to enable him to graduate at that time. He will not have more than three tardinesses in any one month and no absences without the prior approval of Joe Davis, except in the case of illness. Joe Davis will assure that a school transportation allowance is included on the monthly budget.

Joe Davis will arrange a meeting between William, his school counselor, and Joe during April, 1974, to investigate the possibility of a grant to help William attend classes in automotive repair at Poxtland Community College next year. If William is unable to obtain a grant, Joe will talk to the Admisaions Officer to try to get William's tuition waived. 


\section{EMPLOYMENT}

William is to continue working a minimum of twenty hours per week during the school year at Killen's Auto Repair shop. Hia take home pay is $\$ 120.00$ per month out of which William will provide his own entertainment and clothing as well as his total rent $(\$ 75.00)$.

Beginning in mid-June, 1974, William will begin full-time employment for $\mathrm{Mr}$. Killen and will provide his total living expenses between July 1, 1974, and September 15, 1974. If it is arranged for William to attend achool in September, the subsidy program will resume with a financial schedule similar to the one of May.

By August 1, 1975, William will be totally self-sufficient financially. Joe Davis will help him plan his budget, if necessary, and advise him in such areas as health insurance, credit purchasing, etc., until at least November 1, 1975 , unless William wishes to discontinue this assistance earlier.

\section{PROGRAM COMPLETION}

William Jones will have completed the program in all financial areas by August 1, 1975. Should he misuse his funds or be a party to trouble serious enough as to interfere with his ability to adequately function in either school or employment, he will be subject to dismissal at a hearing of the Independent Iiving Subsidy Program evaluation committee. William has the right to appeal a recommended dismissal from the program if that is recommended by Joe Davis.

I, William Jones, understand my obligations and rights as set forth in the above agreement. I will do my best to comply. Signed:

I, Joe Davis, understand my obligations in the above agreement and will be available to Willfam whenever possible. I will do all that is feasible to help assume William's success in this program.

Signed: 


\section{To the Caseworkers:}

The following is a questionnaire being administered to each of the adolescents you have in the IISP. We designed the questionnaire in an attempt to measure changes in the areas indicated on the review reports (i.e., additional school credits, money earned, cooperation with worker, responsibility).

We are asking you to fill out a questionnaire for each youngster you have in the IISP. The questions are designed to be answered by the adolescents in the program. However we are asking you to answer each question as you would if you were asked how it fits (applies to) your client. We do not want you to answer it as you think you client did but as you think and feel about the client(s) you have in the program.

We are aware some of the questions (especially in the last section) may imply "middle class" values which may not apply to the population. They are values which do influence, however, and for that reason have been included.

Thank you for your cooperation. Maxy Gossart

Pat Frawley

PSU School of Social Work 
To the Past or Present Members of the Independent Living

Subsidy Program:

The following questionnaire is part of an evaluation study of the Independent Iiving Subsidy Program. This study has been requested by the Children's Services Division, and is being conducted by students from Portland State University School of Social Work.

As you may know the program you are enrolled in is new and experimental. We have designed this questionnaire to help us evaluate the effects of the ILSP. Your responses will provide us with information about how successful the program has been, and also show us what areas might benefit from improvement. We feel that this information is very important to the future of the program, and we therefore ask you to give some thought to your answers.

Finally, we offer this guarantee to you: that you will remain anonymous and that your responses will be treated with respect and confidence.

Thank you for your cooperation. Mary Gossart

Pat Frawley

PSU School of Social Work 


\section{Identifying Information}

$\frac{\frac{1}{2}}{\frac{20}{4 .}}$

Age:

Sex:

years

Race: Black mele monthe Pemele 4. Date entered program: White other (please specify month year

Educational Information

1. Please circle the highest grade which you have completed in echool.

$\begin{array}{llllllllll}6 & 7 & 8 & 9 & 10 & 11 & 12 & 13 & 14 & 15\end{array}$

2. If you have been enrolled in and attending any educational programs at any time while in the ILSP fill in the following table (educational programs include such things as high school, GED programs, vocational school, college)

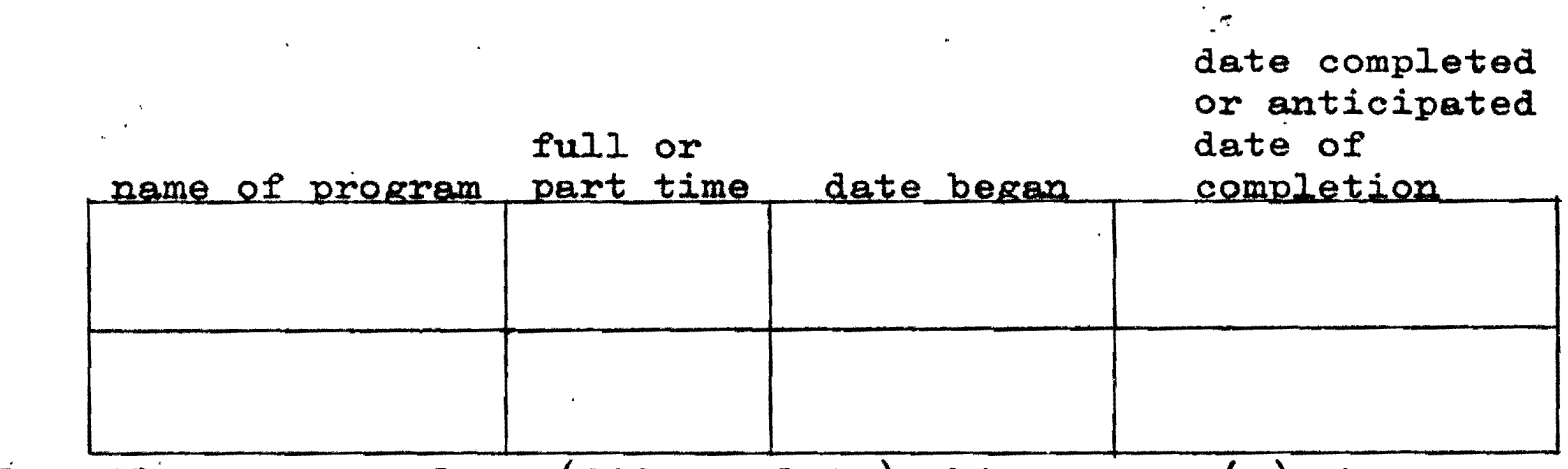

3. When you complete (did complete) this program(s) what will (did) you receive?

Program \#I diplome certificate license other (please specify

Program \#2 diplome certificate Iicense other (please specify

4. I am otill in the process of completing an educational program but am much closer to finishing than when I began it. circle one: doesn't strongly undecided disagree $\operatorname{apply}$ agree 
5. My performance in the educational Program(s) was on the average (circle one):

Program HI

above average

Program \#2

above average

$$
\begin{array}{lll}
\text { average below average failing } & \\
\text { average below average failing }
\end{array}
$$

Employment

1. Please list all the jobs, if any, you have had since entering the IISP.

\begin{tabular}{|l|l|l|l|l|l|}
\hline $\begin{array}{l}\text { place of } \\
\text { employment }\end{array}$ & $\begin{array}{l}\text { nature } \\
\text { of work }\end{array}$ & $\begin{array}{l}\text { amount } \\
\text { earmed }\end{array}$ & $\begin{array}{l}\text { dates of } \\
\text { employment }\end{array}$ & $\begin{array}{l}\text { full of } \\
\text { part time }\end{array}$ & $\begin{array}{l}\text { reason } \\
\text { lesving }\end{array}$ \\
\hline & & & & & \\
\hline & & & & & \\
\hline
\end{tabular}

2. Which otetement best describes how you got these jobs? my own initiative

with a little help, mostly my own initiative combination of my initiative and help from others some initiative on my part, mostly through the help of others it was just handed to me

3. Once you started at any of these jobs did you have to learn some new tasks to do the job? yes no

4. If so please describe the new tasks or work skills you had to learn to do at your job.

5. How long did it take for you to feel comfortable doing these new tasks? circle one: month 2-3 one 2-3 or more weeks week days or less 
6. I feel the new tasks I learned will make it easier for me to find another job when I need to. (circle one) strongly agree undecided disagree strongly agree disagree

7. What do you want to be doing when you have completed the IISP?

8. I feel my current efforts in work and/or school are helping me to reach this goal. (circle one) strongly agree undecided disagree strongly agree disegree

\section{Moner Management}

1. While in the IISP has your income changed from month to month? yes no

2. How much money (net income, after taxes) do you have to live on each month?

3. While in the IISP has the amount of money you earned from employment changed from month to month? yes no

4. Since entering the IISP what is the amount of money you have contributed to your support through employment? Please indicate whether this is per month or the total amount you have contributed since entering the IISP.

5. Do you plan some sort of budget each month? (circle one) always sometimes rarely never

6. Does anyone assist you with this? (circle one) always sometimes rarely never

7. If so, who? 
8. Please list how much you spend each month on these various items:

rent and utilities

food

school expenses transportetion clothing entertainment other

9. I am able to budget and regularly meet my bills and expensea. (circle one)

alwaye sometimes rarely never

10. Money problems come up due to circumstances beyond my control (i.e., necessary unexpected expenses, late checks, etc.) circle one always sometimes raxely never

11. Money problems come up due to my own difficulties in managing it. (circle one)

always sometimes rarely never

12. Have you opened a checking and/or savings account? yeв no

You and Your Worker

1. My worker and I have made a contract. yes no

2. When I agreed to the contract there was nothing in it I wanted to change, take out, or put in. (circle one) strongly agree undecided disagree strongly agree disagree

3. I think we both intended to do all of the things stated in the contract when we agreed to it. (circle one) strongly agree undecided disagree strongly agree disagree

4. There are thinge we agreed to do but haven't done. (circle one)

strongly agree undecided disagree strongly agree disagree

5. It is not really important to either of us that these things haven't been done. (circle one) strongly agree undecided disagree strongly agree disagree 
6. I felt that by following the contract I would get what I wanted out of the IISP. (circle one) strongly agree undecided disagree strongly agree diøagree

7. I feel that my worker is helping me get what I want out of the IISP. (circle one)
etrongly
agree
undecided
disegree
strongly
agree
disagree

8. I feel I can rely on my worker to be available to help me if I need it. (circle one)

atrongly agree undecided disagree strongly agiree

disegree

2. I truat my worker. (circle one)

strongly agree undecided disagree strongly

agree

disagree

10. On the average how many times do you see or talk with your caseworker? 2-3 times a week once $a$ week twice a month once $a$ month Iese than once a month

1I. Are you usualiy the one to initiate these contacts? (circle one)

always sometimes rarely never

12. For the most part I have found the number of contacts to be: (circle one)

more than necessary adequate inadequate

\section{About You}

The following otatements ask you to tell us how you feel about yourself now as compared with a year ago. In responding to these statements, please use the following scale:

4 - true for me all or most of the time

$\bar{B}$ - very often true for me

$\bar{C}$ - occasionally true for me

$\bar{D}$ - sometimes but infrequently true for me

$\underline{\underline{B}}$ - raxely or almost never true for me

1. I act now with more assurance (self confidence) and am not as shy. (circle one)
A
B
c
D
E 
A - true for me all or most of the time

$\bar{B}$ - very often true for me

$\bar{C}$ - occasionaliy true for me

$\bar{D}$ - sometimes but infrequently true for me

$\underline{\underline{E}}$ - rarely or almost never true for me

2. I feel more now that I'm a person of worth and on an equal plane with others. (circle one)
A
B
C
D
E

3. I am more likely now to express my opinions and not worry about what others may think. (circle one)
$\Delta$
B
C
$\mathrm{D}$
$\mathrm{E}$

4. I am better able now to make good decisions about the problems I face. (circle one)
A
$\mathrm{B}$
C
D $\quad$ B

5. I feel more confidence now that I can make things turn out the way I want them to. (circle one)
A.
B
D
E

6. I like to meet new people more now: (circle one)
A. B
C
D
E

7. I feel more confident that I can handie problems which may aribe in the future. (circle one)
A
B
c
D
$\mathrm{B}$

8. I find I have more friends now. ' (circle one)
A
$B$
C
D B

2. I have more what I would consider close friends now, i.e., regular boy/girl friend. (circle one)
A
$B$
$D$
E

10. I am more satisfied now with the friendships I have. (Circle one)
A $B$ C
D
E

11. I get along better now with my parents. (oircle one)
A $B$
$B$ C
D
E

12. I get along better now with my brothers and/or sisters. (circle one)
A B C
D
E

13. I get along better now with other relatives. (circle one)

14. I get along better now with the people I work and/or go to school with. (circle one)
A
$B$
C
D
E 
A - true for me all or most of the time

$\underline{B}$ - very often true for me

$\bar{C}$ - occasionally true for me

$\bar{D}$ - sometimes but infrequently true for me

$\underline{E}$ - rarely or almost never true for me

15. I get along better with the people who supervise me at work and/or school. (circle one)

More About You

1. I have regular contact with various members of my fanily. (circle one)

$\begin{array}{lllll}A & B & C & D & E\end{array}$

2. I have overdrawn on my bank accounts. (circle one)

$\begin{array}{lllll}A & B & C & D & E\end{array}$

3. I've mun up lot of bills. (circle one)
A. B
C
D $\mathrm{E}$

4. I pay my bills on time. (circle one)
A
$B$
C
D $\quad \mathbf{E}$ 5. I never miss school or rork unless I'm sick. (circle one)

6. When I am unable to go to work I call in to let them know I will not be in. (circle one)

A B C D D

7. If I tell somebody I'II do something I usually do it. (circle one)
A $B$ C
D $\quad E$

8. I am usually clean and well groomed. (circle one)
A
$B$
D
$\mathrm{E}$

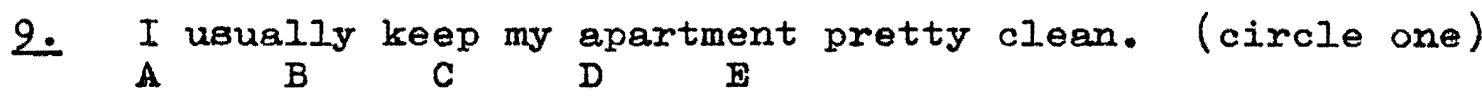

10. I usually shop for my food and prepare my own meals.

11. I usually eat things that are good for me. (circle one)
A
$B$
C $D$ E

12. When I am sick or have something physically wrong I have it taken care of. (circle one)
A.
$\mathrm{B}$
C
$\mathrm{D}$
E 
Background and Cost Data on ILSP Participants 


\begin{tabular}{|c|c|c|c|c|c|c|c|c|c|c|c|c|c|c|}
\hline Name & $\begin{array}{l}\text { Date } \\
\text { referred } \\
\text { to csp } \\
\end{array}$ & $\begin{array}{l}\text { Date } \\
\text { connitted } N \\
\text { to CSD } \\
\text { or giD } \\
\text { by court }\end{array}$ & $\begin{array}{l}\text { No.of } \\
\text { subitt. } \\
\text { carc } \\
\text { placenents }\end{array}$ & $\begin{array}{l}\text { Date } \\
\text { entered } \\
\text { ILSp } \\
\end{array}$ & $\begin{array}{l}\text { No.mos. } \\
\text { in } \\
\text { IISP }\end{array}$ & $\begin{array}{l}\text { Ave. } \\
\text { budget } \\
\text { per } \\
\text { month }\end{array}$ & $\begin{array}{l}\text { Total } \\
\text { child's } \\
\text { cost to } \\
\text { bucget }\end{array}$ & $\begin{array}{l}\text { Ave. CsD } \\
\text { cost to } \\
\text { budget } \\
\text { per mo. }\end{array}$ & $\begin{array}{l}\text { Total } \\
\text { CSD } \\
\text { cost } \\
\text { in ILSP }\end{array}$ & $\begin{array}{l}\text { Alternate } \\
\text { plan and } \\
\text { cost per } \\
\text { month }\end{array}$ & $\begin{array}{l}\text { Total } \\
\text { alternate } \\
\text { plan cost }\end{array}$ & $\begin{array}{l}\text { Difference } \\
\text { between } \\
\text { ILSP and } \\
\text { alternate } \\
\text { plan cost }\end{array}$ & $\begin{array}{l}\text { Date } \\
\text { graduated }\end{array}$ & $\begin{array}{l}\text { Reason } \\
\text { referred } \\
\text { to CSD } \\
\end{array}$ \\
\hline$A$ & 58 & 58 & 4 & $2 / 72$ & 8 & $\$ 225$ & $\$ 250$. & $\$ 227$. & $\$ 1816$ & $\begin{array}{l}\text { MacLaren } \\
\$ 1400\end{array}$ & $\$ 11,200$ & $+\$ 9384$ & $10 / 74$ & Neglect \\
\hline B & $3 / 72$ & $3 / 7.2$ & 4 & $3 / 74$ & 10 & $\$ 260$. & $\$ 825$. & $\$ 185$. & $\$ 1850$. & $\begin{array}{l}\text { MacLaren } \\
\$ 1400 .\end{array}$ & $\$ 14,000$ & $+\$ 12,250$. & $1 / 75$ & $\begin{array}{l}\text { Emotionally } \\
\text { disturbed }\end{array}$ \\
\hline $\mathrm{C}$ & $2 / 74$ & $\begin{array}{l}\text { Vol. } \\
\text { Commitment }\end{array}$ & $t 2$ & $3 / 74$ & 2 & $\$ 257$ & $\$$ & $\$ 257$ & $\$ 514$ & $\begin{array}{l}\text { Foster } \\
\text { Care } \\
\$ 139 . \\
\end{array}$ & $\$ 278$ & $-\$ 236$ & $5 / 74$ & $\begin{array}{l}\text { Eamily } \\
\text { disruption }\end{array}$ \\
\hline$D$ & 68 & $\begin{array}{l}\text { Vol. } \\
\text { Commitmont }\end{array}$ & $\begin{array}{r}13 \\
+ \\
\end{array}$ & $4 / 74$ & 10 & $\$ 231$ & $\$ 966$. & $\$ 134$. & $\$ 1340$ & $\begin{array}{l}\text { MacLaren } \\
\$ 1400 \text {. }\end{array}$ & $\$ 14,000$ & $+\$ 12,600$ & $1 / 75$ & Pre-delinquent \\
\hline $\mathrm{E}$ & $3 / 74$ & $\begin{array}{l}\text { vol. } \\
\text { Commitment }\end{array}$ & 3 & $4 / 74$ & 10 & $\$ 236$ & $\$ 780$. & $\$ 158$ & $\$ 1580$ & $\begin{array}{l}\text { Group } \\
\text { Home } \\
\$ 440 . \\
\end{array}$ & $\$ 4,400$ & $+\$ 2.820$ & $2 / 75$ & $\begin{array}{l}\text { Juvenile Co. } \\
\text { contacts }\end{array}$ \\
\hline$F$ & 64 & 64 & 6 & $4 / 74$ & 10 & $\$ 243$ & $\$ 0$ & $\$ 243$. & $\$ 2430$ & $\begin{array}{l}\text { Dammasch } \\
\text { Hospital } \\
\$ 1095 \text {. } \\
\end{array}$ & $. \$ 10,950$ & $+\$ 8,520$ & $\begin{array}{l}\text { still in } \\
\text { program }\end{array}$ & $\begin{array}{l}\text { Dependency - } \\
\text { neglect }\end{array}$ \\
\hline G & 64 & 64 & 6 & $4 / 74$ & 10 & $\$ 250$ & $\$ 200$ & $\$ 232$ & $\$ 2320$ & $\begin{array}{l}\text { MacLaren } \\
\$ 1400 .\end{array}$ & $\$ 14,000$. & $+\$ 11.680$ & $\begin{array}{l}\text { still in } \\
\text { program }\end{array}$ & $\begin{array}{l}\text { Dependency - } \\
\text { neglect }\end{array}$ \\
\hline $\mathrm{H}$ & $3 / 71$ & $3 / 71$ & 2 & $5 / 74$ & 9 & $\$ 300$ & $\$ 860$. & $\$ 214$ & $\$ 1926$ & $\begin{array}{l}\text { OCI } \\
\$ 737 .\end{array}$ & $\$ 6,633$. & $+\$ 4,707$ & $\begin{array}{l}\text { still in } \\
\text { program }\end{array}$ & $\begin{array}{l}\text { Delinquency, } \\
\text { parole from } \\
\text { Maclaren }\end{array}$ \\
\hline$I$ & $10 / 72$ & $10 / 72$ & 4 & $5 / 74$ & 9 & $\$ 250$ & $\$ 1070$. & $\$ 143$. & $\$ 1287$ & $\begin{array}{l}\text { Ilillcrest } \\
\$ 1440 .\end{array}$ & $\$ 12,960$ & $+\$ 11,673$ & $\begin{array}{l}\text { still in } \\
\text { program }\end{array}$ & $\begin{array}{l}\text { Out of control- } \\
\text { prostitution }\end{array}$ \\
\hline
\end{tabular}




\begin{tabular}{|c|c|c|c|c|c|c|c|c|c|c|c|c|c|c|c|}
\hline Nams & $\begin{array}{l}\text { Date } \\
\text { referred } \\
\text { to cso }\end{array}$ & $\begin{array}{l}\text { Date } \\
\text { cominitted } \\
\text { to CSD } \\
\text { or PWo } \\
\text { by court }\end{array}$ & $\begin{array}{l}\text { No. of } \\
\text { subst. } \\
\text { caxe } \\
\text { placements }\end{array}$ & $\begin{array}{l}\text { Date } \\
\text { entered } \\
\text { Insp }\end{array}$ & $\begin{array}{l}\text { No.mos. } \\
\text { in } \\
\text { ItSP }\end{array}$ & $\begin{array}{l}\text { Ave. } \\
\text { budget } \\
\text { per } \\
\text { month }\end{array}$ & $\begin{array}{l}\text { Total } \\
\text { child's } \\
\text { cost to } \\
\text { budget }\end{array}$ & $\begin{array}{l}\text { Ave.CSD } \\
\text { cost to } \\
\text { budget } \\
\text { per mo. }\end{array}$ & $\begin{array}{l}\text { Total } \\
\text { csD } \\
\text { cost } \\
\text { In ILSP } \\
\end{array}$ & $\begin{array}{l}\text { Alternate } \\
\text { plan and } \\
\text { cost per } \\
\text { month. }\end{array}$ & $\begin{array}{l}\text { Total } \\
\text { alternate } \\
\text { plan cost }\end{array}$ & $\begin{array}{l}\text { Dif: } \\
\text { bets } \\
\text { ILSE } \\
\text { alto } \\
\text { plar }\end{array}$ & $\begin{array}{l}\text { erence } \\
\text { en } \\
\text { and } \\
\text { inate } \\
\text { cost } \\
\end{array}$ & $\begin{array}{l}\text { Date } \\
\text { graduated }\end{array}$ & $\begin{array}{l}\text { Reason } \\
\text { re'ferred } \\
\text { to C30 }\end{array}$ \\
\hline $\mathbf{J}$ & 71 & $\begin{array}{l}\text { Vol. } \\
\text { commitment }\end{array}$ & $t$ & $12 / 74$ & 2 & $\$ 250$. & $\$ 126$. & $\$ 287$. & $\$ 374$. & $\begin{array}{l}\text { Aid to } \\
\text { disabled } \\
\text { ox SSI } \\
\text { S140. }\end{array}$ & 280. & $\begin{array}{c}-\$ \\
.\end{array}$ & $\begin{array}{l}94 . \\
.\end{array}$ & $\begin{array}{l}\text { still in } \\
\text { program }\end{array}$ & Delinquency \\
\hline K & $10 / 73$ & $\begin{array}{l}\text { Vol. } \\
\text { commitment }\end{array}$ & $t$ & $10 / 74$ & 4 & $\$ 250$. & $\$ 75$. & $\$ 235$. & $\$ 940$. & $\begin{array}{l}\text { Group } \\
\text { home } \\
\$ 440 .\end{array}$ & $\$ 1,760$ & $+\$$ & 800 . & $\begin{array}{l}\text { still in } \\
\text { program }\end{array}$ & $\begin{array}{l}\text { Rejected by } \\
\text { family }\end{array}$ \\
\hline$I_{1}$ & $7 / 71$ & $7 / 71$ & 2 & 4.74 & 10 & $\$ 260$. & $\$ 529$. & $\$ 121$. & $\$ 1210$ & $\begin{array}{l}\text { Hillcrest } \\
\$ 1400 \text {. }\end{array}$ & $\$ 14,000$ & $+\$ 1$ & 790 & $\begin{array}{l}\text { still in } \\
\text { program }\end{array}$ & Abuse/neglect \\
\hline
\end{tabular}

